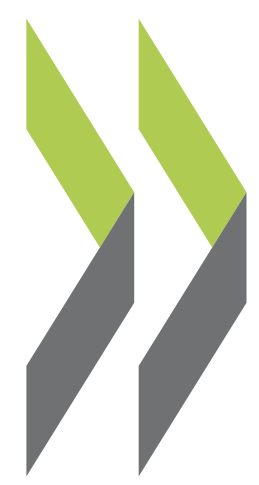

OECD Social, Employment and Migration Working Papers No. 84

\title{
Pension Schemes \\ for the Self-Employed in OECD Countries
}

Jongkyun Choi 
Organisation de Coopération et de Développement Économiques

Organisation for Economic Co-operation and Development

09-Apr-2009

DIRECTORATE FOR EMPLOYMENT, LABOUR AND SOCIAL AFFAIRS

English text only

EMPLOYMENT, LABOUR AND SOCIAL AFFAIRS COMMITTEE

OECD SOCIAL, EMPLOYMENT AND MIGRATION WORKING PAPERS No. 84

PENSION SCHEMES FOR THE SELF-EMPLOYED IN OECD COUNTRIES

Jongkyun Choi

JEL Classficiation: H55; J23

All Social, Employment and Migration Working Papers are now available through OECD's Internet website at http://www.oecd.org/els/workingpapers 


\title{
DIRECTORATE FOR EMPLOYMENT, LABOUR AND SOCIAL AFFAIRS
}

\author{
http://www.oecd.org/els
}

\section{OECD SOCIAL, EMPLOYMENT AND MIGRATION WORKING PAPERS}

\author{
http://www.oecd.org/els/workingpapers
}

This series is designed to make available to a wider readership selected labour market, social policy and migration studies prepared for use within the OECD. Authorship is usually collective, but principal writers are named. The papers are generally available only in their original language - English or French - with a summary in the other.

Comment on the series is welcome, and should be sent to the Directorate for Employment, Labour and Social Affairs, 2, rue André-Pascal, 75775 PARIS CEDEX 16, France.

The opinions expressed and arguments employed here are the responsibility of the author(s) and do not necessarily reflect those of the OECD

\author{
Applications for permission to reproduce or translate \\ all or part of this material should be made to: \\ Head of Publications Service \\ OECD \\ 2, rue André-Pascal \\ 75775 Paris, CEDEX 16 \\ France
}

Copyright OECD 2009 


\section{AFFILIATIONS AND ACKNOWLEDGEMENTS}

Jongkyun Choi was working at the Social Policy Division of the OECD at the time of completion of work reported in this paper. The paper benefited from comments from members of the pension team the Social Policy Division, in particular from Andrew Reilly, Edward Whitehouse and Asghar Zaidi. Nevertheless, the paper represents the personal views of the author. 


\section{SUMMARY}

The self-employed workers make up a small but significant minority of the workforce in many OECD countries. Moreover, transitions into and out of self-employment have become much more common for a larger group of workers. It is therefore of critical importance to review and assess the pension schemes available to self-employed workers across OECD countries. Given employment and income patterns commonly observed for this subgroup, it is also important to address the issue of compliance and enforcement towards a formal affiliation of this group to pension schemes on offer. This paper reviews three key aspects of pension schemes available to self-employed workers: coverage, contributions and benefits. In each part, analyses are undertaken not just by describing the rules governing these schemes but also looking into their actual functioning in terms of compliance and enforcement.

Key findings include the fact that the self-employed are covered by the same pension schemes as those of employees in the majority of countries. One important difference is that, while employees share the contribution burden with their employers, the self-employed workers in most cases pay the full pension contribution from their own income. The rules for pension entitlements, on the other hand, are usually almost identical to those that apply to employees. One key conclusion emerging from this paper is that the pension provision for the self-employed is a matter of practical implementation of existing schemes rather than overhauling pension rules for these schemes. Low coverage is a common problem for this group in some OECD countries, as they belong to the informal sector and their incomes are hard to identify. Contribution evasion or under-reporting of income by the self-employed is prevalent even in some countries with high per capita income. This has implications as these self-employed workers will have lower levels of pension incomes at retirement. In some cases, low contributions coupled with relatively generous pension rights also raise an issue of equity in the provision of pensions for the self-employed and employees. 
DELSA/ELSA/WD/SEM(2009)12

\section{RESUMÉ}

Dans beaucoup de pays de l'OCDE, les travailleurs indépendants constituent, au sein de la population active, une minorité faible par la taille mais d'importance significative. En outre, pour un nombre accru de travailleurs, le passage au statut d'indépendant et l'abandon de ce statut est un processus bien plus courant aujourd'hui. En conséquence, il est crucial d'examiner et évaluer les régimes de pension qui sont à la disposition des travailleurs indépendants dans les différents pays de l'OCDE. Compte tenu de la structure de l'emploi et de celle du revenu généralement observées au sein de cette population, il importe également de s'intéresser au respect de l'obligation d'affiliation formelle de ces travailleurs aux régimes de pension qui leur sont proposés et aux moyens de les y contraindre. Ce document examine trois aspects clés des régimes de pension auxquels les travailleurs indépendants peuvent s'affilier : couverture, cotisations et prestations. Dans chaque partie, les analyses proposées ne se contentent pas de décrire les règles régissant ces dispositifs, mais portent aussi sur leur fonctionnement concret du point de vue du respect de l'obligation d'affiliation et des instruments de coercition.

Les principales observations englobent le fait que, dans la majorité des pays, les travailleurs indépendants sont couverts par les mêmes régimes de retraite que les salariés, à ceci près, et la différence est de taille, que si les salariés partagent le poids des cotisations avec leurs employeurs, les travailleurs indépendants payent dans la plupart des cas les deux parts sur leur propre revenu. Par ailleurs, les règles régissant les droits à pension des indépendants sont généralement presque identiques à celles s'appliquant aux salariés. Une conclusion essentielle se dégage de ce document : en matière de retraite, la question qui se pose pour les travailleurs indépendants concerne l'application pratique des dispositifs existants et non la remise à plat des règles. Dans quelques pays de l'OCDE, les indépendants se heurtent à un même problème, celui du faible niveau de couverture, car cette catégorie de travailleurs relève du secteur informel, et ses revenus sont difficiles à cerner. La fraude fiscale et la sous-déclaration des revenus sont très répandues chez les travailleurs indépendants, même dans des pays où le revenu par habitant est élevé. Ce phénomène n'est pas sans conséquence car au moment de la retraite, le niveau de revenu que procurera à ces travailleurs leur pension sera plus modeste. Dans certains cas, le faible niveau des cotisations conjugué à la générosité des droits à pension soulève aussi un problème d'équité dans le financement des pensions des travailleurs indépendants et des salariés. 


\section{TABLE OF CONTENTS}

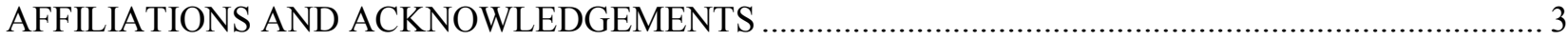

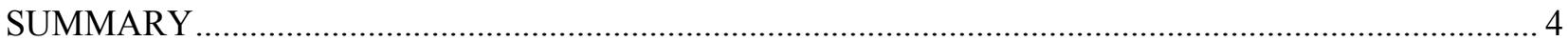

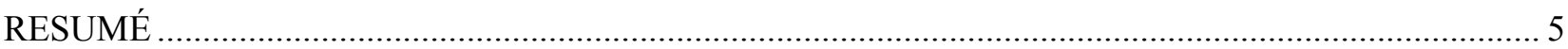

PENSION SCHEMES FOR THE SELF-EMPLOYED IN OECD COUNTRIES ….............................. 7

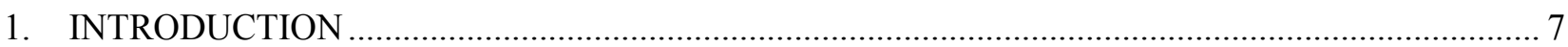

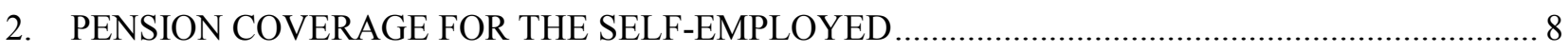

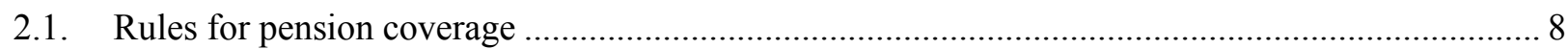

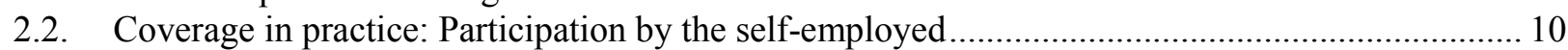

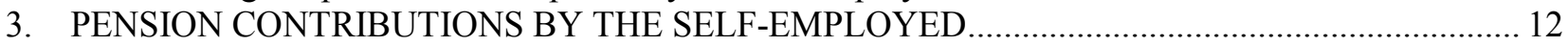

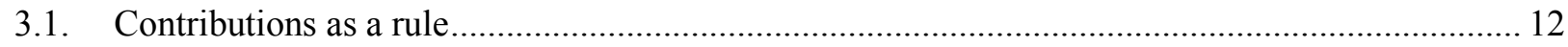

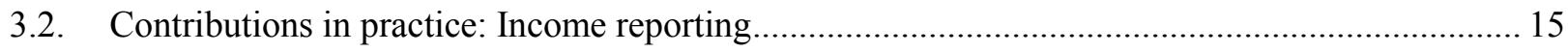

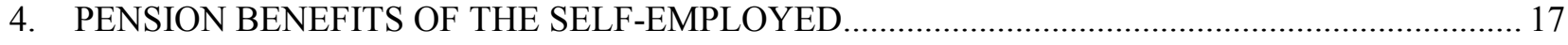

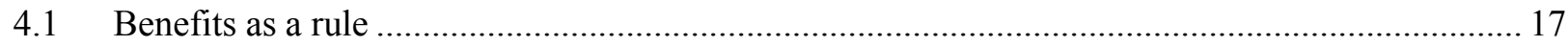

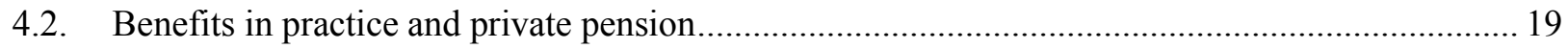

5. PENSION REFORMS IN SCHEMES FOR SELF-EMPLOYED IN OECD COUNTRIES................ 21

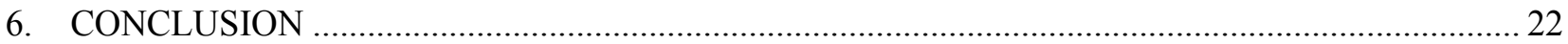

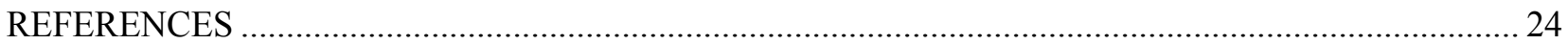

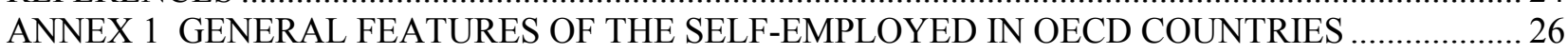

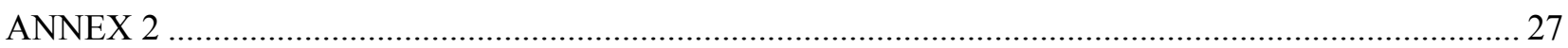

ANNEX 3 OVERVIEW OF PENSION RULES FOR DEPENDENT EMPLOYEES AND THE

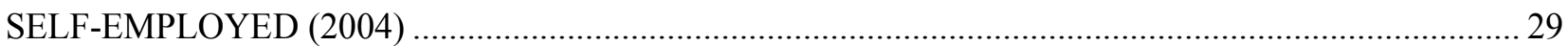

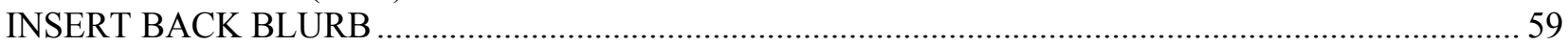

\section{Tables}

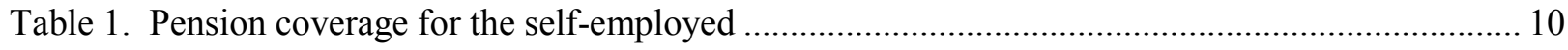

Table 2. Pension contributions rule for the self-employed.................................................................. 14

Table 3. Estimated pension contributions by the self-employed (2004) ............................................... 16

Table 4. Estimated pension contributions by the self-employed (2004) ............................................... 18

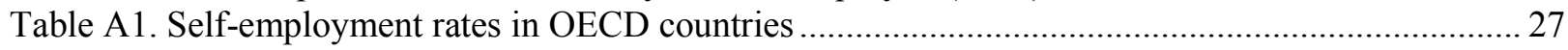

Table A2. Comparison of pension benefit levels between employee and the self-employed .................. 28

\section{Figures}

Figure 1. Difference in benefit levels between the self-employed and employees

\section{Boxes}

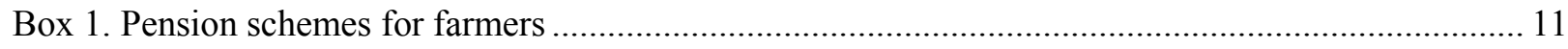

Box 2. Private pension schemes for the self-employed in Ireland and the United States ........................ 20 
DELSA/ELSA/WD/SEM(2009)12

\section{PENSION SCHEMES FOR THE SELF-EMPLOYED IN OECD COUNTRIES}

\section{INTRODUCTION}

1. Pension schemes were originally set up to offset social risks of dependent workers followed by the industrial revolution. The systems were largely developed on the basis of what had existed for industrial workers rather than the self-employed who were thought to be able to provide for their own social protection. After World War II, coverage of pension schemes was extended further. In most countries, regardless of the type of pension system adopted, the self-employed are nowadays entitled to pension benefits. But the self-employed differ from the group of employees in several respects. Most notably, their incomes are less stable and personal incomes are often difficult to distinguish from revenues necessary to keep the business running. Therefore, many countries have decided to treat the self-employed differently from the employees in the provision of retirement income. In some countries, self-employed persons are integrated in the employees' scheme which provides more or less the same level of benefits for both groups. In others they are covered by separate schemes with different methods of benefit calculation.

2. The lack of studies in this area reflects the generally low attention to pension schemes for the self-employed. Academics and policy-makers are more preoccupied with issues related to pension schemes for the much larger population of employees. In addition, concerns related to low contribution compliance and difficulty of measuring actual incomes of the self-employed are not apparent in many OECD countries. An often-held opinion is that the business assets of the self-employed constitute the best source of retirement income for the self-employed. It is, however, worth looking into this issue, because, in a few countries, especially those with low per-capita income, old-age income security for this group is still a major policy concern. In addition, higher incidence of in-work poverty within the self-employed, and the growing briefness and low-paid income of many new forms of self-employed jobs provoke concerns for their income security after retirement. Furthermore, to boost labour market integration of the young unemployed and also older workers, many countries have introduced policies to encourage selfemployment (OECD, 2000).

3. The self-employed make up a substantial minority of the workforce in many OECD countries (OECD, 2007). In 2005, the total self-employment rates ranged from under $8 \%$ in Luxembourg, Norway and the United States to over one third in Korea, Mexico, Greece and Turkey. On average, nearly 17\% of total civilian employment is in self-employment in 2005. Over the period from the early 1990 s, selfemployment rates have been falling in most countries although there have been small increases in Sweden and Germany and much larger increases in the Czech Republic and Slovak Republic. Generally, selfemployment rates are highest in countries with low capita income although Italy, with a self-employment rate of $27 \%$, is an exceptional case with Ireland and Spain. ${ }^{1}$

1. More detailed information about the self-employed is provided in the Annex 1. 
4. Reviewing the pension systems for the self-employed - how are they treated under different schemes and what happens to them in reality - is no easy matter because of the great variety of systems within OECD countries and limited data and analyses on this issue. In this paper, the topic will be approached based on three key aspects of pension schemes: pension coverage, pension contributions and pension benefits. In each session, the rules and the actual functioning of the systems in practice will be dealt with distinctively. Finally, some general reform trends in selected OECD countries will be reviewed. Summary charts of the employees' schemes and the self-employed' schemes in individual OECD countries are provided in the Annex 3.

\section{PENSION COVERAGE FOR THE SELF-EMPLOYED}

5. There is a wide range of approaches to pension provision for the self-employed in OECD countries. These can be categorised into four different types.

\subsection{Rules for pension coverage}

6. First, some countries have pension schemes that are based on the principle of national insurance. These schemes cover the whole population in the same way without considering the employment status (Type 1: Basic pension with or without distinctive supplementary pensions of the self-employed). To supplement this generally basic pension, most countries have complementary pension schemes which are earnings-related and financed by contributions. The participation of the self-employed in these latter schemes can be voluntary or compulsory. In Ireland and New Zealand, where there are only basic pension schemes, complementary schemes are voluntary. Australia, Japan, the Netherlands and the United Kingdom grant basic pensions to the self-employed, but do not require compulsory participation of selfemployed in the second tier earnings-related scheme (although participation in these schemes for employees is mandatory in Australia and quasi-mandatory in the Netherlands). Other countries such as Canada, Finland, Iceland, Norway and Sweden have mandatory earnings-related schemes for the selfemployed.

7. The second group of countries has an earnings-related pension scheme which is financed by contributions, and covers both salaried employees and the self-employed within the same scheme (Type 2: Earnings-related pensions with no distinction for the self-employed). Countries in this group are Austria, the Czech Republic, Hungary, Korea, Portugal, Slovak Republic, Switzerland, Turkey and the United States. In many cases, small amounts of earnings-related pensions for low-income groups - whether they are self-employed or employees - are topped up by a minimum pension guarantee. In Hungary, for example, HUF 20100 per month (equivalent to around 45\% of average earnings) is provided as a minimum pension to pensioners who have contributed for at least 20 years. In Switzerland, which has both public earnings-related schemes and mandatory occupational pension schemes, the self-employed are required to join the earnings-related scheme, but may participate in the occupational pension scheme voluntarily.

8. A third group of countries has special separate schemes for the self-employed as a whole or for individual groups of self-employed (Type 3: Separate pensions for the self-employed). This is the case in Belgium, France, Germany, Greece, Italy, Luxembourg, Poland and Spain. Often, farmers are covered by separate schemes which are not part of the overall scheme for the self-employed. In Poland, for example, all non-agricultural self-employed are incorporated into the general scheme for the salaried workers but 
farmers have separate arrangements. Even though the self-employed have separate pension schemes, the same rules apply to dependent employees and the self-employed in Luxembourg and Spain.

9. Mexico is the only OECD country where there is no obligation for the self-employed to join any pension scheme (Type 4: No mandatory pensions for the self-employed). Participation of the selfemployed and informal sector workers is voluntary. Since this group makes up a large share of the Mexican work force, the newly introduced funded scheme covered only one-third of Mexico's workforce in 1999. In Hungary, although farmers can join on a voluntary basis, it should be noted that they are excluded from the mandatory pension system.

10. The pension scheme for self-employed in Germany is worth a special mention. Coverage of German pension systems has been extended, but there is no general, universal coverage of the whole population. Part of the self-employed are completely excluded from collective pension schemes and thus have to rely exclusively on private provision. A special private pension product was recently introduced targeted specifically to this group ("Rürup-Rente"). German self-employed persons are affiliated to different pension schemes depending on their professions. Craftsmen and journalists are assimilated with salaried workers and come under a pension insurance fund for employees. The self-employed who are members of professional chambers such as doctors, lawyers and architects have to join the pension schemes of the respective chamber. These schemes are run by decentralised private institutions. Other selfemployed persons such as retailers may resort to voluntary insurance.

11. Pension coverage of the self-employed in individual OECD countries is shown in Table 1. The shaded area in Table 1 shows a mandatory pension scheme for the self-employed. For example, in Australia, the self-employed join the shaded Targeted pension mandatorily, but there is no obligation for them to join the non-shaded Defined contribution pension. Further details about the differences between employees and the self-employed are provided in Annex 3. Overall, the table shows that, in most countries, the difference in pension coverage between employees and the self-employed is not very large. Separate schemes for the self-employed are operated in 11 countries, including Poland which has a separate scheme only for farmers while the other self-employed are integrated into the employees' scheme. Eight countries exclude the self-employed from all or part of their public or mandatory occupational pension schemes. In most countries, the self-employed are allowed to join or benefit from at least the primary basic or targeted pension scheme. The impact of this difference in coverage on the pension level varies depending on the weight of the basic or targeted pension in the overall pension entitlements. 
Table 1. Pension coverage for the self-employed

Difference between employees and the self-employed

\begin{tabular}{|c|c|c|c|c|c|c|}
\hline Country & \multicolumn{5}{|c|}{ Coverage of the self-employed } & Type \\
\hline Australia & \multicolumn{3}{|c|}{ Targeted } & \multicolumn{2}{|c|}{ Defined contribution (superannuation) } & 1 \\
\hline Austria & \multicolumn{5}{|c|}{ Earnings-related } & 2 \\
\hline Belgium & \multicolumn{5}{|c|}{ Earnings-related (separate) } & 3 \\
\hline Canada & \multicolumn{3}{|c|}{ Basic } & \multicolumn{2}{|c|}{ Earnings-related } & 1 \\
\hline $\begin{array}{l}\text { Czech } \\
\text { Republic }\end{array}$ & \multicolumn{3}{|c|}{ Basic } & \multicolumn{2}{|c|}{ Earnings-related } & 1 \\
\hline Denmark & Basic & Targeted & $\begin{array}{c}\text { Defined } \\
\text { contribution (ATP) }\end{array}$ & $\begin{array}{c}\text { Defined } \\
\text { contribution (SP) }\end{array}$ & Occupational & 1 \\
\hline Finland & \multicolumn{2}{|c|}{ Targeted } & \multicolumn{3}{|c|}{$\begin{array}{c}\text { Earnings-related (separate) for farmers (MYEL) and other self- } \\
\text { employed (YEL) }\end{array}$} & 1 \\
\hline France & $\begin{array}{r}\text { Earnir } \\
(\text { se }\end{array}$ & $\begin{array}{l}\text { igs-related } \\
\text { parate) }\end{array}$ & \multicolumn{3}{|c|}{$\begin{array}{l}\text { Mandatory occupational for farmers and other self-employed } \\
\text { (CNAVPL, CNBF, etc.) }\end{array}$} & 3 \\
\hline Germany & \multicolumn{5}{|c|}{$\begin{array}{c}\text { Earnings-related (separate) for farmers and other self-employed } \\
\text { (doctors, lawyers, etc) }\end{array}$} & 3 \\
\hline Greece & \multicolumn{5}{|c|}{ Earnings-related (separate) for farmers (OAEE) and other self-employed (OGA) } & 3 \\
\hline Hungary & \multicolumn{3}{|c|}{\begin{tabular}{l|l} 
Earnings-related & Define \\
\end{tabular}} & contribution (volunts & nbership for farmers) & 2 \\
\hline Iceland & \multicolumn{5}{|c|}{ Mandatory occupational } & 1 \\
\hline Ireland & \multicolumn{5}{|c|}{ Basic } & 1 \\
\hline Italy & \multicolumn{5}{|c|}{ Earnings-related (separate) } & 3 \\
\hline Japan & \multicolumn{5}{|c|}{ Earnings-related } & 1 \\
\hline Korea & \multicolumn{5}{|c|}{ Earnings-related } & 2 \\
\hline Luxembourg & \multicolumn{5}{|c|}{ Earnings-related (separate) for farmers and other self-employed } & 3 \\
\hline Mexico & \multicolumn{5}{|c|}{\begin{tabular}{l|ll} 
Minimum & Funded
\end{tabular}} & 4 \\
\hline Netherlands & \multicolumn{3}{|c|}{ Basic } & \multicolumn{2}{|c|}{$\frac{\text { Funded }}{\text { Occupational }}$} & 1 \\
\hline New Zealand & \multicolumn{5}{|c|}{ Basic } & 1 \\
\hline Norway & \multicolumn{3}{|c|}{ Basic } & \multicolumn{2}{|c|}{ Earnings-related } & 1 \\
\hline Poland & \multicolumn{3}{|c|}{$\begin{array}{l}\text { Earnings-related (separate for } \\
\text { farmers only) }\end{array}$} & \multicolumn{2}{|c|}{ Defined contribution (not for farmers) } & 2 \\
\hline Portugal & \multicolumn{5}{|c|}{ Earnings-related } & 2 \\
\hline $\begin{array}{l}\text { Slovak } \\
\text { Republic }\end{array}$ & & & Earr & ngs-related & & 2 \\
\hline Spain & & Earnin & -related (separate) & or farmers and othe & mployed & 3 \\
\hline Sweden & Target & \begin{tabular}{l|l} 
ed & Earnin \\
\end{tabular} & selated $\quad$ Defined & \begin{tabular}{l|l} 
contribution & Qua \\
\end{tabular} & datory Occupational & 1 \\
\hline Switzerland & & argeted & Earnings-relate & Manc & ccupational & 1 \\
\hline Turkey & & & Earr & ngs-related & & 2 \\
\hline $\begin{array}{c}\text { United } \\
\text { Kingdom }\end{array}$ & & Basic & Target & & ings-related & 1 \\
\hline United States & & & Earr & ngs-related & & 2 \\
\hline
\end{tabular}

Note: 1. The shaded area means a covered (mandatory participation) pension scheme for the self-employed.

2. "Type" shows a corresponding pension type among 4 types which are described above.

Sources: EC (2004 and 2006) and various national sources.

\subsection{Coverage in practice: Participation by the self-employed}

12. There is only very limited evidence on the actual participation of the self-employed in pension schemes. Amongst OECD countries, data on evasion by self-employed persons is available in only a few cases. For example, in Japan where the basic pension system covers the entire population, non-registered and unpaid persons account for $17.2 \%$ of the expected members of the "number 1 category" group. This group mostly consists of the self-employed and farmers with small numbers of unemployed persons and students. More than 3 million self-employed persons are in arrears with respect to their contribution payments. As a result, the payment rate of contributions for the basic pension (ratio of the contributions that are due and actually paid, except for exempted contributions) was $62.8 \%$ for the 2002 fiscal year. The corresponding figure for the employees' scheme was 97.6\% in 2001 (Japan MHLW, 2005). 
13. In Korea where there is only one pension scheme which covers both salaried workers and the self-employed, the regionally insured group ${ }^{2}$ which mostly consists of the self-employed, farmers, unemployed and students, accounts for more than half (55.1\%) of all insured persons in 2004. Among them, $49.8 \%$ (4.7 million people) are formally exempted from paying contributions ${ }^{3}$. Insured persons who cannot pay contributions or have difficulties in paying because they have no, or only a very low, income are exempted from contributions rather than losing the insured status. However, one study (Kim and Kang, 2004) estimates that around $20 \%$ of this exempt group are suspected of having capacity to pay contributions. Nearly $50 \%$ of persons in arrears are also thought to have enough income to pay their delayed pension contributions. Some people in this category even join private pension schemes.

14. As mentioned above, participation of the self-employed in the funded pension scheme in Mexico works on a voluntary basis. One statistic shows that in $2001,64 \%$ of the labour force ${ }^{4}$ - excluding civil servants and oil workers - were affiliated in the pension scheme (Mesa-Lago, 2002). Even though detailed classification of the non-participants is not available, this figure nearly coincides with $37 \%$ of selfemployment rates to total civilian employment in that year (OECD, 2007). Generally, in Latin America, coverage of self-employed workers is much lower than that of salaried workers. Making coverage mandatory is not necessarily the appropriate solution, because of the low capacity of many self-employed to contribute and the existence of serious obstacles for enforcement. In Mexico, like other Latin American countries, the self-employed are the main component of the informal sector.

\section{Box 1. Pension schemes for farmers}

Farmers in many OECD countries obtain special treatment in the old-age pension system. First, pension provision for farmers is sometimes separate from that for the rest of society, including other self-employed. Austria, Finland, France, Germany, Greece, Poland and Spain have set up separate pension schemes for farmers.

In general, this fragmentation is accompanied by concessions in contributions and internal government transfers to fund the benefits (OECD, $2005 \mathrm{a}$ ). Korean farmers (also including fishermen) receive government subsidies for their contributions, the amount of which depends on the individual's income level. In Austria, Finland and Germany, government provides a substantial amount of financial aid, equivalent to nearly three-quarters of total pension expenditure, to the farmers' pension scheme (Mairhuber, 2003 and EC, 2004). In France, farmers' own social security contributions pay for only $18 \%$ of the total expenses of their social security system, with the remaining balance financed by government. While farmers account for only $3.8 \%$ of the total population, estimates of the pension fund balance show that, in 2040, the farmers' pension fund deficit will reach $2 \%$ of GDP which is equivalent to that of the scheme for private-sector employees (France, 2003).

The Polish special farmer's pension system (KRUS) which was set up towards the end of the 1970s shows the most extreme situation (Poland, 2004). Farmers pay substantially lower contributions than employees but are offered comparable pension benefits. Their contributions are less than one-third of the contributions that would be paid by a minimum wage earner in the general system (ZUS). As a result, Polish government subsidies cover more than $95 \%$ of the total pension expenditure for farmers. In 2002, all KRUS spending amounted to $2.1 \%$ of GDP.

2. Identical contribution rates and benefits calculation formula are applied to both the workplace-based group - mainly employees - and the regionally insured group - mainly the self-employed. Main difference is that while employees share the burden of paying contributions with employers, the self-employed within the regionally insured group should pay all the contributions themselves.

3. Although the period of exception of contributions payment is not regarded as insured period which is a basis of calculation of benefits, insured persons may increase their insured period by paying postponed contributions later.

4. The compliance rate among these affiliates is much lower. Only $28 \%$ of the labour force, or $45 \%$ of pension affiliates are active contributors (Mesa-Lago, 2002). 
15. In Turkey, which has the highest incidence of self-employment amongst OECD countries, approximately one-quarter of the working age population, or around half the labour force, pay social security contributions (Turkey, 2006). Given that those benefiting from the generous pension schemes are generally formal-sector salaried workers, it is estimated that a substantial number of the self-employed are not covered by the public pension system. For example, although participation in the self-employed pension scheme is supposedly mandatory, $91 \%$ of farmers do not participate. Furthermore the level of the anti-poverty means-tested pension is extremely low: estimated at $6 \%$ of average earnings in 2002 (OECD, $2005 b$ ). In addition, it has very strict eligibility criteria, including the absence of someone responsible for the elderly person's care. This further emphasises the seriousness of the coverage problem amongst the self-employed and that other measures to improve the weak coverage have been insufficient.

\section{PENSION CONTRIBUTIONS BY THE SELF-EMPLOYED}

16. The contribution rates for the self-employed are, in the majority of cases, identical to those of employees. Reflecting the difficulty of measuring the real income level of the self-employed, however, different methods of calculating the contribution base are used. Under-reporting of income by the selfemployed is acknowledged in many countries and this has implications for the actual pension contributions made by the self-employed.

\subsection{Contributions as a rule}

17. While contributions for employees are shared between workers and employers, in most cases, the self-employed have to pay the full pension contribution by themselves. This does obviously not apply to purely tax-financed basic pensions for the self-employed, such as those in Australia and New Zealand. As Table 2 shows, there are only two countries in which the self-employed pay only part of the pension contributions: Austria and Luxembourg. Among the 21 OECD countries which have comparative data for contribution rates of employees and the self-employed, on average, employees pay 7.6 percentage points out of the total contribution rate of $20.3 \%$. The self-employed, however, contribute $18.2 \%$ out of total $18.8 \%$ (Table 2). In most countries, no significant difference of total contribution rates between both groups is reported. The average contribution rate gap of $2.4 \%$ (employee $19.1 \%$ and the self-employed $16.7 \%$ ) is largely due to the large differences between the two groups in Italy and Mexico. The Netherlands has very narrow contribution gap between both groups.

18. Some countries apply special treatment to pension scheme financing of the self-employed. In such special schemes, the self-employed do not pay the whole sum of employer and employee contributions. For example, in Austria, salaried workers pay contributions of $10.25 \%$ out of a total of $22.8 \%$ (12.55\% by employer), but farmers and other self-employed persons pay $15 \%$ and $17.5 \%$, respectively. The remaining part of $7.8 \%$ and $5.3 \%$ are called "partner co-payment" and financed by general revenue (Republic of Austria, 2005). As a result, in 2001, the proportion of the tax-based finance made up about $41 \%$ for the scheme of the self-employed in trade and business, and reached $74 \%$ for the farmers' scheme (Mairhuber, 2003). The financial support of the government for employees' scheme amounted to only $15 \%$ of total financing. This higher subsidy for these schemes is justified by the fact that employees, unlike the self-employed, benefit from government payments for periods of unemployment, sickness and child-care and also the self-employed pay additional trade tax. 
19. In Finland, the contributions for self-employed persons and farmers are fixed annually by the government. In 2004, the rate was $21.4 \%$ of declared earnings. However, farmers are entitled to a contribution reduction, which depends on the insured pensionable earnings. As farmers' earnings are generally low, the level of their average contribution is lower: on average $10.5 \%$ of declared earnings in 2004 (SSA, 2004). In Luxembourg, of the total $24 \%$ of contributions for self-employed, the government pays $8 \%$ which is equivalent to financial support for the employees from the government. In Poland and Spain, the self-employed farmers are also subject to low contribution rates. There are also other cases of indirect financial support. While the Korean government levies the same level of contribution rates on selfemployed farmers as those on employees, at least one-third of the contributions of the lowest income group are paid by the government. The Japanese government also supports one-third of total finance of the basic pension for the self-employed. The Greek government has supported two-thirds of total pension finance for farmers since 1998 (Mylonas and Maisonneuve, 1999).

20. Many OECD countries use net professional income of the self-employed (income minus the necessary business expenditures) as the contribution base. In some countries, a different base is used: for example, in the Czech Republic, the contribution rate for the self-employed is $28 \%$ of declared earnings, and declared earnings are defined as $50 \%$ of the difference between income and expenses. In this case, this calculation base for the self-employed' contribution has to be at least half of the average gross monthly wage in the national economy. ${ }^{5}$ As a result, on average, the contribution base amounts to only $30 \%$ of that of wage earners in 2004 (The Czech government, 2005). Similarly, in Hungary, the self-employed are required to pay the same rates of contribution, but based on the minimum wage not on income actually earned (Hungary, 2004). Polish self-employed have to pay $19.52 \%$ of declared earnings, however a lower threshold for the contribution base applies which is equal to $60 \%$ of the calculated average wage in the economy set by the budget law.

5. A flat-rate CZK 4709 is applied in 2006, if declared earnings for a full-time self-employed person are less than half of $50 \%$ of the average monthly wage. 
Table 2. Pension contributions rule for the self-employed

\begin{tabular}{|c|c|c|c|c|}
\hline \multirow{2}{*}{ Country } & \multicolumn{2}{|c|}{ Employee } & \multicolumn{2}{|c|}{ Self-employed } \\
\hline & Total & Employee & Total & Self-employed \\
\hline Australia & 9.0 & 0.0 & 0.0 & 0.0 \\
\hline Austria & 22.8 & 10.25 & 22.8 & 17.5 (farmer: 15) \\
\hline Belgium $^{a}$ & $37.94\left(16.36^{\mathrm{b}}\right)$ & $13.07\left(7.5^{b}\right)$ & 19.65 or $14.16^{c}$ & 19.65 or 14.16 \\
\hline Canada & 9.9 & 4.95 & 9.9 & 9.9 \\
\hline Czech Republic & 28 & 6.5 & 28 & 28 \\
\hline Denmark & 16+DKK 2682 & 6+DKK 894 & 1+DKK 894 & 1+DKK 894 \\
\hline Finland & $21.4^{d}$ & 4.6 & 21.4 & 21.4 (farmer: 10.5) \\
\hline France & 23.95 & 9.65 & 23.05 & 23.05 \\
\hline Germany & 19.5 & 9.75 & 19.5 & 19.5 \\
\hline Greece & 20 & 6.67 & 20 & 20 \\
\hline Hungary & 26.5 & 8.5 & 26.5 & 26.5 \\
\hline Iceland & 15.64 & 4 & 15.64 & 15.64 \\
\hline Ireland & & \multicolumn{2}{|c|}{ No separate pension contribution } & \\
\hline Italy & 32.7 & 8.89 & 19 & 19 \\
\hline Japan & 13.58 & 6.79 & $¥ 13,300 /$ month & $¥ 13,300 /$ month \\
\hline Korea & 9 & 4.5 & 9 & 9 \\
\hline Luxembourg & 24 & 8 & 24 & 16 \\
\hline Mexico & 6.275 & 1.75 & 0 & 0 \\
\hline Netherlands & 28.05 & 19.15 & 27.95 & 27.95 \\
\hline New Zealand & & \multicolumn{2}{|c|}{ No pension contribution } & \\
\hline Norway & & \multicolumn{2}{|c|}{ No separate pension contribution } & \\
\hline Poland ${ }^{\mathrm{e}}$ & 32.52 & 16.26 & 32.52 & $\begin{array}{c}32.52 \text { (farmer: PLN } \\
663 / \text { year) }\end{array}$ \\
\hline Portugal & & \multicolumn{2}{|c|}{ No separate pension contribution } & \\
\hline Slovak Republic & 26 & 7 & 26 & 26 \\
\hline Spain & & \multicolumn{2}{|c|}{ No separate pension contribution } & \\
\hline Sweden & 18.91 & 7 & 18.91 & 18.91 \\
\hline Switzerland & $9.8+14-36^{f}$ & $4.9+7-18$ & 9.2 & 9.2 \\
\hline Turkey & 20 & 9 & 20 & 20 \\
\hline United Kingdom & & \multicolumn{2}{|c|}{ No separate pension contribution } & \\
\hline United States & 12.4 & 6.2 & 12.4 & 12.4 \\
\hline Average* $^{*}$ & 20.3 & 7.6 & 18.8 & 18.2 \\
\hline
\end{tabular}

Note: aGlobal contributions for sickness, maternity, disability and old-age, etc.

b Pensions only. $37.94 \%$ and $13.07 \%$ are for the global contributions

c $\quad 19.65 \%$ for earnings between $€ 9,067.99$ and $44,289.23$, and $14.16 \%$ for earnings between $€ 44,289.23$ and $€ 65,273.48$.

d Average number. According to the number of persons employed, from $16.9 \%$ to $24.0 \%$.

e Old-age pension only.

f $\quad 9.8 \%$ for earnings-related and $14-36 \%$ for mandatory occupational according to their age.

*For averaging, Belgium, Denmark, Ireland, Japan, New Zealand, Norway, Portugal, Spain, Switzerland and the United

Kingdom are excluded.

Sources: EC (2004 and 2006), SSA (2004, 2005 and 2006) and various national sources.

21. Some countries give the self-employed the option of choosing between several contribution rates themselves. In the Czech Republic, the self-employed person can determine the level of the assessment base for pension contribution. In Hungary, the pension contribution base is the income which the self- 
employed declare for themselves. In Greece, the self-employed use the presumptive criteria for assessing income and their contributions are calculated according to income classes that are set by the payers themselves (Greece, 2001). In Portugal, the reference income which is the contribution base is chosen by the self-employed person from a range of 1.5 to 12 times the national minimum wage (SSA, 2006). Spanish self-employed are essentially free to choose their covered earnings - the contribution base between a floor and a ceiling legislated annually (Boldrin and Jiménez-Martín, 2003).

\subsection{Contributions in practice: Income reporting}

22. The issue of pension contributions of the self-employed is closely related with the issue of taxation. In most OECD countries, the tax treatment of the self-employed is the Achilles heel of income taxation. In general, the self-employed face low effective tax rates, as they have more deductions and credits regarding expenses, or under-report income due to self-assessment and weak auditing (Van den Noord and Heady, 2001). The self-employed are responsible for their own income assessment and are a particularly difficult group of contributors to monitor.

23. Inequalities between pension contributions for the self-employed and employees are reported in many countries. For instance, in the Czech Republic, due to the lower contribution base together with the self-assessment of the base, the contribution obligation of the self-employed is considerably smaller than that of employees. In 1999, the average assessment base for employees was CZK 14 165, while that of the self-employed was CZK 3 474. Due to high degree of redistribution between different income groups in the pension system, this results in a heavy redistribution from the salaried workers to the self-employed. One of the reasons for pension deficit is the advantageous treatment of the self-employed, whose contributions are continuously falling (Král, 2000). One of the problems is the widespread practice among the self-employed to set the reported income too low, especially when they report their income for the first time. For this reason, the pension contribution amount is lower than that of employee (Tuomine, 1997).

24. In Greece, the self-employed receive generous pensions relative to their contributions. It is estimated that while their real contributions are below half of those made by private employees, the difference of the benefit level between both groups is not so large. The self-employed often choose to place themselves in low income contribution classes - significantly below the average income of the sector - as they can still benefit from the main component of the earnings-related scheme which is broadly equal to pensions corresponding to that of employees (Greece, 2001; Mylonas and Maisonneuve, 1999). This is likely to have contributed to the large share of non-agricultural self-employed in Greece. The same challenge is encountered by the Korean pension system. The self-employed group's reported income on which contributions and benefits are based is only $60 \%$ of that of employees. Income under-reporting is a serious problem not only among lower-income groups but also among many high-income groups such as doctors and lawyers.

25. In Poland, pension contribution of the self-employed and farmers is not at all or weakly linked to income. Polish law does not allow the Social Insurance Institution - ZUS - to monitor the actual income of the self-employed. The basis for the contribution is the declared income, and almost all the self-employed declare the minimum level of income ( $60 \%$ of the average wage), which indirectly shows how common income under-reporting is amongst the self-employed (ILO, 2004). According to the Household Budget Survey, the self-employed constitute the socio-economic group that has the lowest incidence of poverty. Thus, actual incomes of the self-employed should be substantially higher than the declared minimum. Portuguese self-employed also pay low pension contributions. They tend to choose the lower contribution 
base allowed by the system (i.e. the minimum national wage) in order to minimise pension contributions (Portugal, 2001). ${ }^{6}$

26. Likewise, in Spain, a large proportion of self-employed workers report earnings equal to the legislated floor (Boldrin and Jiménez-Martín, 2003). This is common until the age of 50; thereafter, there is a sudden increase of reported contribution basis which is due to the way that the final salary enters into the calculation of the pension benefit - the earnings measure for pension benefits is based on pay over the last 15 years. To reduce this behaviour, a different ceiling applies to the self-employed aged 50 and over who had not reported higher earnings in the previous years. While the contribution ceiling for normal selfemployed is 1.9 times the average earnings in manufacturing and services, that for the self-employed who under-report their income before age 50 ceases to be around the average earnings in 2000. In short, the self-employed who falsely report their income before age 50 are not allowed to increase their contributions after 50, due to low contribution ceiling. In 2003, nearly $45 \%$ of Spanish, formerly self-employed, pensioners, who represent $25 \%$ of all pensioners, had contributed for less than 20 years and $44 \%$ of them were receiving a minimum pension. This reflects a minimum pension "purchase" strategy by these workers (Spain, 2005). Because of the existence of a minimum pension, the self-employed reduce their pension wealth if they increase their contribution periods.

Table 3. Estimated pension contributions by the self-employed (2004)

\begin{tabular}{|c|c|c|c|c|c|c|c|c|}
\hline \multirow{2}{*}{ Country } & \multicolumn{4}{|c|}{ Contribution amount } & \multicolumn{2}{|c|}{$\begin{array}{c}\text { Self-employed } \\
\text { contribution ratio }\end{array}$} & \multirow{2}{*}{$\begin{array}{l}\text { Self- } \\
\text { employment } \\
\text { rate }\end{array}$} & \multirow{2}{*}{ Area } \\
\hline & $\begin{array}{l}\text { Employee } \\
\text { (A) }\end{array}$ & $\begin{array}{l}\text { Employer } \\
\text { (B) }\end{array}$ & $\begin{array}{l}\text { Sub total } \\
\text { (C) }\end{array}$ & $\begin{array}{c}\text { Self-employed } \\
\text { (D) }\end{array}$ & $\begin{array}{c}\text { Gross } \\
(\mathrm{D} / \mathrm{C}+\mathrm{D}) \\
\end{array}$ & Adjusted & & \\
\hline Austria & 8802 & 9314 & 18116 & 1675 & $8.5 \%$ & $10.0 \%$ & $12.8 \%$ & pension \\
\hline Canada & 17804 & 17804 & 35608 & 2117 & $5.6 \%$ & $5.6 \%$ & $9.5 \%$ & pension \\
\hline Czech & 53463 & 176811 & 230274 & 13634 & $5.6 \%$ & $5.6 \%$ & $16.9 \%$ & pension \\
\hline Finland & 2525 & 11449 & 13974 & 707 & $4.8 \%$ & $4.8 \%$ & $12.8 \%$ & pension \\
\hline Germany & 135280 & 152530 & 287810 & 25380 & $8.1 \%$ & $13.5 \%$ & $12.1 \%$ & SSC \\
\hline Italy & 31547 & 120688 & 152235 & 20847 & $12.0 \%$ & $18.3 \%$ & $28.4 \%$ & SSC \\
\hline Luxembourg & 1272 & 1292 & 2564 & 331 & $11.4 \%$ & $13.2 \%$ & $6.7 \%$ & SSC \\
\hline Norway & 55415 & 98762 & 154177 & 9514 & $5.8 \%$ & $11.4 \%$ & $7.4 \%$ & SSC \\
\hline Portugal & 4463 & 10288 & 14751 & 542 & $3.5 \%$ & $4.8 \%$ & $26 \%$ & SSC \\
\hline Slovak & 38395 & 114631 & 153026 & 8362 & $5.2 \%$ & $5.5 \%$ & $12 \%$ & SSC \\
\hline Spain & 16053 & 71983 & 88036 & 9049 & $9.3 \%$ & $11.8 \%$ & $18.1 \%$ & SSC \\
\hline Turkey & 11258 & 14402 & 25660 & 6484 & $20.2 \%$ & $31.8 \%$ & $49.2 \%$ & SSC \\
\hline US & 346423 & 397280 & 743703 & 39459 & $5.0 \%$ & $7.5 \%$ & $7.6 \%$ & SSC \\
\hline Average & & & & & $8.1 \%$ & $11.1 \%$ & $16.1 \%$ & \\
\hline
\end{tabular}

Note: 1. Unit for contribution amount is euro or currency of individual country.

2. Adjustment is made considering the difference of contribution rates between employees and the self-employed.

3. Contributions of unemployed are included in those of the self-employed.

4. "SSC" means social security contributions.

Source: OECD (2006 and 2007).

27. Among 13 OECD countries, on average, while the self-employment rate is $16.1 \%$ of total civilian employment, their pension or social security contributions account for $11.1 \%$ of total pension or social security contributions (Table 3). Rather big differences between the self-employment rate and the self-

6. While the employer's and employee's combined social security contribution rate for a skilled worker is around $34 \%$, the self-employed normally contribute the equivalent of $16 \%$ of the gross salary of an average production worker (Portugal, 2001). 
employed' contribution burden are shown in many countries except Austria, Germany and the United States. In the Czech Republic, the self-employed labour force, $16.9 \%$ of total civilian employment pays only $5.6 \%$ of total pension contributions. This difference can be explained by various factors, even though some more in-depth analysis is needed. It could testify the widespread contribution evasion among the selfemployed. Otherwise, it could reflect that the self-employed may truly have a lower contribution base, even though the same contribution rate as that of employees is applied. If the actual income level of the self-employed is lower than that of employees, their total contribution could take small portion in total contributions. Nevertheless, the large difference between the share of the self-employed in the labour force and their contribution to pension and social security financing may indicate that the self-employed pay less than their real capacity to pay would allow.

\section{PENSION BENEFITS OF THE SELF-EMPLOYED}

28. It is hard to find any significant difference in benefit levels between employees and the selfemployed when looking at the rules of the pension systems. But how do the pension systems for the selfemployed work in reality? In many countries, it is widely acknowledged that it is quite difficult for the national authorities to detect the exact income level of the self-employed. This presents a major obstacle to designing adequate retirement protection as well as reaching wide-spread pension coverage for the selfemployed.

\subsection{Benefits as a rule}

29. With some exceptions, the method of benefit calculation for the self-employed does not differ much from that of wage earners. As Table 4 shows, there are very few countries which apply different rules of benefit calculation. Belgium is the only country with a distinctively different pension formula for the self-employed and employees. In Belgium, where there are three different pension schemes for employees, the self-employed and civil servants, different ways of calculating a pension are used for each group. The minimum pension for the self-employed was far below the poverty threshold $(60 \%$ of the equivalised median income) in 2001, while that of employees, covering all earnings levels, with a full career was at about the same level as the poverty threshold and that of civil servants was above this threshold. To improve the situation of the self-employed, the so-called $1^{\text {st }}$ pillar bis was introduced on 1 July 2006. The aim of this pension is to reduce the difference between the pension of employees and that of the self-employed (Belgian government, 2005).

30. Three countries - Ireland, Poland and Spain - apply slightly different rules, such as the exclusion of early retirement pension. In Greece, the earnings base for employees to calculate benefits is the average over the last 5 years before retirement, while that for the self-employed is based on lifetime average earnings. Some countries which have a separate scheme for farmers - France, Germany and Poland - also have different pension benefit formula for farmers. For example, in France, identical rules are applied to employees and the self-employed in non-agricultural work. But pension schemes for farmers use a different method of calculating benefits which consists of a flat-rate component and a proportional component based on a points system. 
Table 4. Estimated pension contributions by the self-employed (2004)

\begin{tabular}{|c|c|c|}
\hline Country & Rule (difference from employees) & Note \\
\hline Australia & No. & DC: Voluntary \\
\hline Austria & $\begin{array}{l}\text { No. } \\
\end{array}$ & \\
\hline Belgium & $\begin{array}{l}\text { Yes. Different ways of calculating benefits for three schemes } \\
\text { (employee, the self-employed, civil service) }\end{array}$ & Low benefits for the self-employed. \\
\hline Canada & $\begin{array}{ll} & \text { No. } \\
\end{array}$ & \\
\hline Czech & No. & \\
\hline Denmark & No. & ATP: Voluntary \\
\hline Finland & No. & \\
\hline France & No (farmer: Yes). & $\begin{array}{l}\text { Farmer: A flat-rate maximum } \\
\text { pension and a proportional } \\
\text { pension. }\end{array}$ \\
\hline Germany & No (farmer: Yes). & $\begin{array}{c}\text { Farmer: Partial coverage. Benefits } \\
\text { are less than half those of } \\
\text { employees. }\end{array}$ \\
\hline Greece & $\begin{array}{l}\text { Yes (Partial difference. Earnings base: the last } 5 \text { years } \\
\text { salary (employee), lifetime average (the self-employed)). }\end{array}$ & Farmer: Substantially low benefits. \\
\hline Hungary & $\begin{array}{ll} & \text { No. } \\
\end{array}$ & \\
\hline Iceland & No. & \\
\hline Ireland & No. & $\begin{array}{l}\text { Retirement pension payable from } \\
\text { age } 65 \text { is not available. }\end{array}$ \\
\hline Italy & No (But, difference in contribution rate). & $\begin{array}{l}\text { Low benefits for the self-employed } \\
\text { (employee: } 33 \% \text { of contribution } \\
\text { versus the self-employed: } 20 \% \text { of } \\
\text { contribution rate). }\end{array}$ \\
\hline Japan & No. & Earnings-related: $\mathrm{n} / \mathrm{a}$ \\
\hline Korea & No. & \\
\hline Luxembourg & No. & \\
\hline Mexico & Voluntary participation. & \\
\hline Netherlands & No. & Occupational: $\mathrm{n} / \mathrm{a}$ \\
\hline New Zealand & No. & \\
\hline Norway & No. & $\begin{array}{l}\text { Low contribution, but the same } \\
\text { benefits. }\end{array}$ \\
\hline Poland & No (Partial difference. Farmer: Yes). & $\begin{array}{l}\text { Early pension is not available. } \\
\text { Farmer: Contributory part plus } \\
\text { supplementary part. }\end{array}$ \\
\hline Portugal & No. & \\
\hline Slovak & No. & \\
\hline Spain & No (partial difference). & $\begin{array}{l}\text { Partial retirement is not covered. } \\
\text { No pension entitlement before age } \\
65 .\end{array}$ \\
\hline Sweden & No. & Occupational: $\mathrm{n} / \mathrm{a}$ \\
\hline Switzerland & No. & Occupational: Voluntary \\
\hline Turkey & No. & \\
\hline UK & No. & Earnings-related: Voluntary. \\
\hline US & No. & \\
\hline
\end{tabular}

31. Figure 1 shows the difference of benefit levels between the self-employed and employees. Instead of replacement rates, relative pension levels which represent the gross individual pension divided by gross economy-wide average earnings are used. ${ }^{7}$ This data is based on the assumptions set by OECD

7. This is to highlight the difference of benefits between two groups. Because replacement rates tend to increase, as the earnings decrease, that indicator does show little the contrast in this case. 
pension modelling $(\mathrm{OECD}, 2007 \mathrm{~b})$, with the exception of Italy and Spain. In nearly half of the 27 OECD countries $^{8}$ examined here, no difference between a self-employed person and an employee is reported in terms of average pensions relative to average earnings. So if the wage of salaried workers and the income of the self-employed after expenditure for business are identical, then they both have the same level of pension benefits in these countries.

Figure 1. Difference in benefit levels between the self-employed and employees

Relative pension levels as a percentage of economy-wide average earnings, average earners

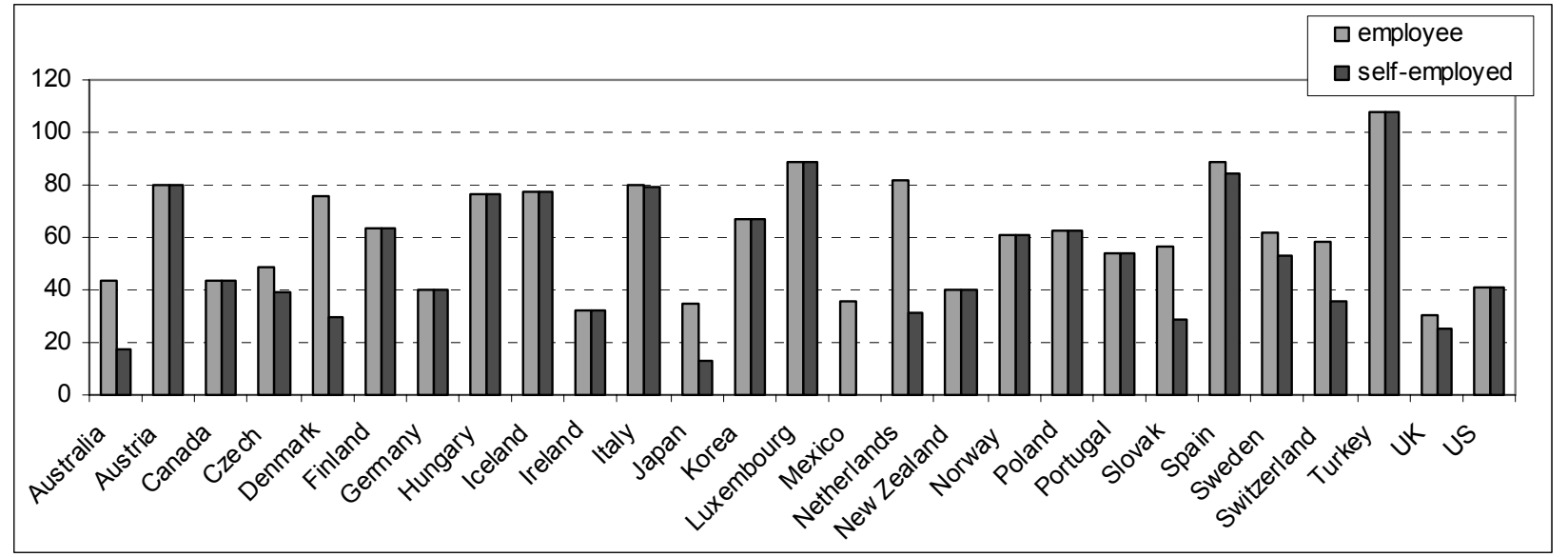

Note: 1. The contribution period is 40 years for Italy and 35 years for Spain.

2. The reference year is 2004, but 2003 for Italy and 2000 for Spain.

Source: OECD Pension Model except OECD (2004) for Italy, and Spain (2001) for Spain.

32. Except in Mexico where no compulsory pension scheme for the self-employed exists, the selfemployed are covered by some kind of pension scheme, at least by the basic or targeted pension. In countries where employees and self-employed persons have different extents of coverage, actual entitlements depend on the weight of pension scheme from which the self-employed are excluded. As Figure 1 shows, the self-employed could experience reductions of the replacement rate ranging from only a little in Italy and over $60 \%$ in the Netherlands, unless they voluntarily join special schemes targeted at the self-employed or save money in private or personal pension plans. There are benefit cuts of over $50 \%$ in Australia, Denmark, Japan, Netherlands and Slovak Republic. Countries which have a relatively small difference - less than $20 \%$ - in pension entitlements for the self-employed also include the Czech Republic, Italy (nearly identical), Spain, Sweden and the United Kingdom. Switzerland is the only country which provides less than $40 \%$ of pension of employees' to the self-employed. On average, among 27 OECD countries, the self-employed receive a pension which is around 18 lower than that of employees (Table A2).

\subsection{Benefits in practice and private pension}

33. In theory, the difference in pension levels between employees and the self-employed is not very large, but in practice, it could be substantial. In many countries, pension entitlements are closely linked with contributory period and earnings level. As discussed above, under-reporting of income by the selfemployed in order to avoid taxes and social security contributions is prevalent in many OECD countries. For instance, in Poland where most self-employed declare their income at the floor level $(60 \%$ of the average wage), the actual relative pension level of the self-employed - as indicated by relative pension

8. Because of lack of information on the self-employed benefit formulae, Belgium, France and Greece are excluded. 
level - is $36.7 \%$ rather than theoretical $62.2 \%$. Likewise, because many Spanish self-employed pay contributions only for the minimum period in order to obtain entitlement to the minimum pension, the pension level drops substantially. In countries where the self-employed are allowed to self assess their income for pension or social security contributions, they tend to choose an income level as low as possible. Greece, Poland, Portugal and Spain are such examples. This strategy results in cuts in benefit levels.

34. In many OECD countries where there is a defined-benefit scheme with a progressive benefit formula, low pension contributions, but relatively high entitlements for the self-employed will result in redistribution from employees to the supposedly low-income self-employed which in fact often have much higher incomes. A solution to this problem would be to introduce a defined-contribution scheme for the self-employed or to reduce the progressiveness of the benefit formula. An example of this is found in Italy where pension reform has resulted in a much less progressive pension system than in the past. Selfemployed persons will experience a much larger cut in the replacement rate than employees. This is mainly due to the lower contributions paid by the self-employed in the new pension system (OECD, 2004). When the Italian self-employed workers retire at 65 with 40 years of contributions and average earnings, their replacement rates will decrease from $79.2 \%$ in 2003 to $61.1 \%$ in 2030 . The numbers for employees are $79.9 \%$ in 2003 and $84.4 \%$ in 2030 respectively. ${ }^{9}$

35. Without actual administrative data for individual countries, it is quite difficult to draw any definite conclusion about the actual pension levels of the self-employed. However, at least for some countries, old-age pensions of the self-employed are lower than those of employees. Pensions of French self-employed persons are fairly low (France, 2001) and the pension level of the Finnish self-employed is lower than that of employees (Tuominen, 1997). Belgium also has low pension provision for the selfemployed.

\section{Box 2. Private pension schemes for the self-employed in Ireland and the United States}

\section{Ireland: Personal Retirement Savings Account (PRSAs)}

This allows adults to contribute to an individual account of their own and benefit from tax relief. The payments through an employer scheme will usually be made once a month. If the payment is done directly by the self-employed, most providers allow very flexible ways: weekly, monthly, quarterly, half-yearly and yearly payments. The insured are free to stop, start and increase their contributions at any time without being charged. They are also allowed to decrease their contributions at any time, as long as they meet the minimum annual contribution levels, if any, set out by the PRSA provider. In each case, the insured are usually required to give the provider advance notice. If the insured do not pay contributions for two years or more and the value of the PRSA fund is $€ 650$ or less, the provider can terminate the PRSA and give the insured a refund of the value of the account.

Source: Consumers' Association of Ireland (2003), Personal Retirement Savings Accounts (PRSAs): A Consumer Guide.

\section{United States: The Keogh Plan}

This is similar to individual retirement accounts plan (IRAs) but have higher contribution limits. If a person has net earnings from self-employment, he/she can make contributions. If the person has a net loss from self-employment, he/she cannot make a contribution for that year. If the insured does not pay the full contribution timely, there may be interest on any underpayment for the period of the underpayment. For the money purchase pension plan or a defined benefit plan, there is a minimum funding requirement. The contributions required to satisfy the minimum funding requirement for a plan year will be considered timely if made by 8 and a half months after the end of that year.

Source: Internal Revenue Service (2005), Retirement Plans for Small Business.

9. These numbers are from Italian national authorities (OECD, 2004). Different assumptions from the OECD pension modelling are used: $1.8 \%$ of annual growth in wages and productivity, $1.4 \%$ of annual GDP growth rate, and $2 \%$ of inflation rate. 
36. One way to supplement the low replacement rate of the self-employed in public pension schemes is to join a private pension scheme which can accommodate fluctuation of income. Very limited evidence is available on this. In Ireland, under the target set by the Irish National Pensions Policy Initiative, pension coverage - a measure of the proportion of the workforce that have supplementary pensions ${ }^{10}-$ for the selfemployed has increased from 27\% in 1995 to 43\% in 2004 (Pension Board, 2005). In the United Kingdom, half of the self-employed population is covered by the private pension scheme in 2002, while the number for employees is $65 \%$ (UK, 2004). According to a survey by a UK insurance company, self-employed people in the UK are under-saving significantly compared to their employed counterparts (Scottish Widows, 2007). Only about one- third of self-employed people are saving enough for old age, while they have greater debts than employees. Two in five (38\%) of them are not saving at all, which is lower than that of private sector employees $(28 \%)$.

\section{PENSION REFORMS IN SCHEMES FOR SELF-EMPLOYED IN OECD COUNTRIES}

37. The self-employed as well as employees have been affected by pension reforms from the early 1990s onward. Even though most of the impact of reform is the same for both groups, some specific features affect the self-employed in particular. One of these measures is the integration of the selfemployed' scheme into the general scheme for employees; another is the increase of contributions paid by the self-employed. All these reform measures are designed to establish more equitable pension systems between employees and the self-employed through monolithic benefit and contribution formulae, and an increase of input by the self-employed. This change is also expected to improve the ability of overall administration to accurately monitor the number of insured persons as well as revenues and expenditures. The establishment of an integrated pension system contributes greater mobility of the workforce between the public, private and self-employed sector.

38. There are several recent examples for the integration of schemes. In Austria, the latest pension reform, implemented in January 2005, established a unified pension system that covers the entire labour force (employee, self-employed and unemployed) including federal civil servants. A unified contribution rate of $22.8 \%$ was set, with a government subsidy for the actual contributions for the self-employed and farmers. In France, to simplify the administrative process, a unified social scheme for craftsmen, trade and industrial self-employed workers was established in 2006. In Greece, a new single fund, "Insurance Organisation for the Self-employed" (OAEE) replaced the three large non-agricultural primary funds for the self-employed: TEBE (craftsmen and other professionals), TAE (retailers) and TSA (motorists). Farmers remain covered by a separate pension scheme (OGA). Based on the reform act which took effect in January 2007, the three separate pension systems in Turkey - private and public sector workers (SSK), civil servants (ES) and the self-employed and farmers (Bag-Kur) - were unified by introducing a single pension formula (Turkey, 2006).

39. The second common reform has been to increase contributions paid by the self-employed. This is to correct excessively favourable treatment for pension contribution by the self-employed. For example, in the Czech Republic, the minimum contribution base for the self-employed was increased from $35 \%$ to $50 \%$ of the difference between income and expenditures, with the base threshold to be equal to half the average wage. In Greece, farmers began to pay contributions to the new basic pension plan in 1998, with the

10. These include Personal Retirement Savings Account (PRSA), Retirement Annuity Contract (RAC), and etc. 
government providing two-thirds of the contributions. Before then, farmers did not make any contributions at all. Their low flat-rate pension was funded from the budget (1.2\% of GDP) and earmarked taxes $(0.5 \%$ of GDP). The new pension plan is expected to provide the opportunity to raise their pension level (Mylonas and Maisonneuve, 1999). The pension contribution rate for Italian self-employed is being gradually increased from 16\% to 19\% by 2014 (Italy, 2000). In Portugal, the reference wage to determine minimum contributions to social security for the self-employed was raised from 1 to 1.5 minimum wages. This is meant to be the first step forward in the direction of levying social contributions including pension contributions as a proportional share of net earnings on the self-employed. Since 2000, in Poland, the selfemployed have to pay social security contributions for persons who work with them, such as assisting family members.

40. Changing patterns of employment careers are one of the factors behind these reform measures. Because more and more people, at least for part of their professional career are self-employed, pension systems need to be adapted to allow this new environment to be fully integrated into pension systems. Austria, Germany and Italy, for example, integrated new types of self-employed work (such as the selfemployed working for only one client) into their statutory pension scheme (EC, 2006). Other changes for the self-employed include the introduction of flexible contribution systems within a certain limit in Denmark and measures for enhancing portability between employees' scheme and the self-employed' in the Netherlands. With effect from 2004, a self-employed person in Denmark can pay an amount corresponding to up to $30 \%$ of the profits into a pension scheme without being bound to making specific payments in subsequent years. This measure which takes into account the fact that profits from selfemployment can vary from one year to another, allows the self-employed person to save up pension when possible. From 2005, in the Netherlands, a formerly self-employed person who becomes an employee or has another job is allowed to transfer his or her pension rights to another pension provider (Dutch government, 2005).

\section{CONCLUSION}

41. Three aspects of pension coverage for the self-employed have been discussed in this paper. In many OECD countries, at least in theory, the self-employed are covered by the same pension schemes as those of employees at nearly the same level, with the exception of Mexico. While employees share the contribution burden with their employers, the self-employed, in most cases, must pay the total pension contribution. The rules for pension entitlements are usually almost identical to those that apply to employees.

42. The issue of the self-employed' pension is a matter of practical implementation rather than that of pension rules. The main problems are compliance and enforcement. In some OECD countries, a substantial part of the self-employed workforce is excluded from pension coverage. Many of them belong to the informal sector and their income levels are very hard to identify. Contribution evasion or under-reporting of income by the self-employed is prevalent even in some countries with high per capita income. This will lead to lower replacement rates at retirement for the self-employed. Under DB schemes with progressive redistribution formulae, low contributions coupled with relatively generous benefits could raise an equity issue of pension provision between the self-employed and employees.

43. The self-employed are generally assumed to secure enough retirement income by selling their business at retirement. Their business may represent accumulated wealth. This seems to be the reason why 
the pension issue for the self-employed has not been considered seriously in many OECD countries. However, in recent years, the number of 'new self-employed', many of whom have come directly from unemployment and set up small companies in the service sector is growing (Lindskog, 2005). More frequent transitions into and out of self-employment are becoming common in the employment histories of a growing share of the population. Those people may not have accumulated enough realisable capital value by the time they retire to provide an adequate retirement income.

44. The changing pattern of labour market, together with the difficulty of enforcing pension rules on the self-employed on an equal base with dependent workers has posed and will pose difficult challenges to the policy-makers in OECD countries. The main issue would be how to build equitable pension systems for the self-employed and employees, while providing the self-employed with enough retirement income security. 


\section{REFERENCES}

Belgian government (2005), Strategy Report on Pensions: 2005, http://ec.europa.eu/employment_social/social_protection/docs/2005/be_en.pdf

Boldrin, M. and S. Jiménez-Martín (2003), Evaluating Spanish Pension Expenditure Under Alternative Reform Scenarios, http://www.micheleboldrin.com/Papers/nber3.pdf

Czech government (2005), National Strategy Report on Adequate and Sustainable Pensions, http://ec.europa.eu/employment_social/social_protection/docs/2005/cs_en.pdf

Dutch government (2005), 2005 National Strategy Report on Adequate and Sustainable Pensions: The Netherlands, http://ec.europa.eu/employment_social/social_protection/docs/2005/nl_en.pdf

EC (2004 and 2006), MISSOC, Brussels.

EC (2006), Adequate and Sustainable Pensions: Synthesis Report 2006, http://ec.europa.eu/employment_social/social_protection/docs/2006/rapport_pensions_final_en.pdf

ILO (2004), Collection of Pension Contributions: Trends, Issues and Problems in Central and Eastern Europe, Budapest.

Japan MHLW (2005), Public Pension Schemes Issues, http://www.mhlw.go.jp/english/org/policy/d1/p3637d4-1.pdf

Kim, S. and S. Kang (2004), Enhancing the Compliance Rate of the Insurers of the region-based National Pension Scheme, Seoul, National Pension Research Institute (in Korean).

Král, J. (2000), “The Czech Pension Reform: Developments after 1989 and future perspective”, Social Security in the Global Village, The Year 2000 International Research Conference on Social Security, Helsinki, 25-27 September 2000.

Lindskog, M. (2005), “The Swedish Social Insurance System for the Self-Employed”, http://skylla.wzberlin.de/pdf/2005/i05-103.pdf

Lisicky, M. (2003), Pension Reform in the Czech Republic: A Gradual Approach, http://www.oenb.at/en/img/lisicky_ftr_103_tcm16-10376.pdf

Mairhuber, I. (2003), “The Austrian Pension Systems”, FORBA Research Report 2/1003, Vienna.

Mesa-Lago, C. (2002), "Reassessing Pension Reform in Chile and Other Countries in Latin America", http://www.adb.org/Documents/Events/2002/SocialProtection/lago_paper.pdf

Mylonas, P. and C. Maisonneuve (1999), "The Problems and Prospects Faced by Pay-as-you-go Pension Systems: A Case Study of Greece", Economic Department Working Papers No. 215, Paris. 
OECD (2000), Employment Outlook, Paris.

OECD (2004), Ageing and Employment: Italy, Paris.

OECD (2005 a), Taxation and Social Security in Agriculture, Paris.

OECD (2005 b), Pensions at a Glance: Public Policies across OECD Countries, Paris.

OECD (2006), Revenue Statistics, Paris.

OECD (2007 a), OECD Factbook 2007, Paris.

OECD (2007 b), Pensions at a Glance: Public Policies across OECD Countries, Paris.

Pension Board (2005), National Pensions Review, Dublin.

Republic of Austria (2005), Report on the Austrian Pension Strategy 2005,

Scottish Widows (2007), Self-employed More Steptoe Than Stelios, http://www.scottishwidows.co.uk/documents/generic/2007_Grantrepreneurs.pdf

SSA (Social Security Administration) (2004, 2005 and 2006), Social Security Programs Throughout the World, http://www.ssa.gov/policy/docs/progdesc/ssptw/

Tuomine, E. (1997), "Self-Employment and Pension Provision for the Self-Employed in Finland", Social Protection and the Development of Self-Employment in Non-Agricultural Occupations, ISSA European Regional Meeting, Paris, 4-5 December 1997.

Van den Noord, P. and C. Heady (2001), "Surveillance of Tax Policies: A Synthesis of Findings in Economic Survey", Economic Department Working Papers No. 303, Paris.

※ OECD Economic Surveys on individual countries are quoted as (country name, publication year). 


\section{ANNEX 1 \\ GENERAL FEATURES OF THE SELF-EMPLOYED IN OECD COUNTRIES}

45. The self-employed population is predominantly male. In more than half of the OECD countries, over $15 \%$ of all men in employment were self-employed. The corresponding figure for women was under $10 \%$ in 2005. In addition, the self-employed have a higher average age than the population in paid employment. The under-35s accounted for only $30 \%$ of all self-employed workers in the European Union. Older self-employed workers (55 or more) were very clearly over-represented in the agricultural group (27\% in comparison with an average of $17 \%$ ). According to the 1996 Second European Survey on Working Conditions, two-thirds of the self-employed were concentrated in the service sector (34\%) and in the sectors of commerce, hotels and restaurants $(30 \%)$. The service sector was becoming even more predominant.

46. According to the 1998 European Foundations survey, in 15 EU member countries and Norway, the average working hours of the self-employed are 48.2 hours, 10.5 hours longer per week, on average, than that of employees. While only $12 \%$ of dependent employees work more than 50 hours per week, almost $50 \%$ of the self-employed do. The survey also shows that a significant proportion (16\%) of the selfemployed work part-time, against $21 \%$ in the case of employed workers.

47. Data on the incomes of the self-employed are both harder to obtain and less reliable than those for salaried workers. Nevertheless, rather outdated studies unanimously agree that the distribution of the income of the self-employed tended to be less equal than that of wage earners. In addition, the selfemployed record generally lower levels of income relative to those of employees. The risk of in-work poverty is more than 2.5 times greater for self-employed workers than for dependent employees. Data for the 15 EU countries suggest that $16 \%$ of the self-employed are classified as the working poor (defined as those earning less than $60 \%$ of the median equivalised household income). Among employees, only $6 \%$ are classified as such in 2003.

Source: OECD Employment Outlook 2000, OECD Factbook 2007, OECD Ageing and Employment series, European Foundation for Improvement of Living and Working Conditions papers. 
ANNEX 2

Table A1. Self-employment rates in OECD countries

As a percentage of total civilian employment

\begin{tabular}{|c|c|c|c|c|c|c|c|c|c|}
\hline & 1990 & 1991 & 1993 & 1995 & 1997 & 1999 & 2001 & 2003 & 2005 \\
\hline Australia & 15.1 & 15.7 & 16.5 & 15.4 & 15.1 & 14.5 & 13.8 & 13.5 & 13 \\
\hline Austria & 14.2 & 13.9 & 13.1 & 14.4 & 13.6 & 13.4 & 13.2 & 12.8 & 13.3 \\
\hline Belgium & 18.1 & 18.3 & 18.9 & 18.8 & 18.6 & 17.8 & &.. & .. \\
\hline Canada & 9.5 & 9.8 & 10.7 & 10.6 & 11.4 & 11.3 & 9.9 & 9.8 & 9.4 \\
\hline Czech Republic & .. & .. & 9.4 & 12 & 12.4 & 14.5 & 15.2 & 17.3 & 16.1 \\
\hline Denmark & 11.7 & 10.9 & 10.8 & 9.6 & 9.1 & 9.1 & 8.9 & 8.8 & 8.7 \\
\hline Finland & 15.6 & 15.3 & 16 & 15.6 & 14.9 & 14 & 13 & 12.9 & 12.7 \\
\hline France & 13.2 & 12.7 & 11.7 & 10.8 & 10.1 & 9.5 & 8.9 & 8.8 & 9 \\
\hline Germany & 10.9 & 9.8 & 10.4 & 10.7 & 10.9 & 10.8 & 11.1 & 11.4 & 12.4 \\
\hline Greece & 47.7 & 46.8 & 46.7 & 46.1 & 45.2 & 42.1 & 39.9 & 39 & 36.4 \\
\hline Hungary & & .. & 18.1 & 18 & 17.4 & 15.7 & 14.5 & 13.5 & 13.8 \\
\hline Iceland & 15.1 & 20.3 & 18 & 19.6 & 17.7 & 17.7 & 16.8 & 14 & 14.3 \\
\hline Ireland & 24.9 & 23.3 & 23.4 & 22.2 & 20.8 & 19.2 & 18.1 & 17.5 & 17.4 \\
\hline Italy & 28.7 & 28.6 & 28.9 & 29.3 & 29.1 & 28.6 & 28.2 & 27.5 & 27 \\
\hline Japan & 22.4 & 21.2 & 19.1 & 18.3 & 17.6 & 17.2 & 15.9 & 15.2 & 14.7 \\
\hline Korea & 39.5 & 37.3 & 37.9 & 36.8 & 36.8 & 37.6 & 36.7 & 34.9 & 33.6 \\
\hline Luxembourg & 9.1 & 8.6 & 8.3 & 8.4 & 8.2 & 7.7 & 7 & 6.8 & .. \\
\hline Mexico & 31.9 & 44 & 43.8 & 40.9 & 39.9 & 37.9 & 36.8 & 37.1 & 35.7 \\
\hline Netherlands & 11.6 & 11.2 & 11.6 & 12.4 & 12.6 & 11.3 & 11.5 & .. & .. \\
\hline New Zealand & 19.7 & 20.4 & 21.2 & 21 & 20.1 & 21.2 & 19.9 & 19.4 & 18.5 \\
\hline Norway & 11.3 & 10.8 & 10.2 & 9.4 & 8.2 & 7.8 & 7.2 & 7.4 & 7.5 \\
\hline Poland & 27.2 & 30 & 31.2 & 29.7 & 28.3 & 26.9 & 28 & 27.3 & 25.8 \\
\hline Portugal & 29.4 & 30.6 & 26.3 & 27.9 & 28.9 & 27.2 & 27 & 26.8 & 25.2 \\
\hline Slovak Republic & .. &.. &.. & 6.5 & 6.3 & 7.7 & 8.4 & 9.8 & 12.7 \\
\hline Spain & 25.9 & 25.2 & 26 & 25.2 & 23.6 & 21.3 & 19.8 & 18.3 & 18.3 \\
\hline Sweden & 9.2 & 9.1 & 10.8 & 11.2 & 10.8 & 10.6 & 10 & 9.6 & 9.8 \\
\hline Switzerland & .. & 11.7 & 12.7 & 12.7 & 13.8 & 14 & 12.9 & 11.9 & 11.2 \\
\hline Turkey & 61 & 62 & 57.8 & 58.5 & 55.4 & 55 & 52.8 & 49.4 & 45.8 \\
\hline United Kingdom & 15.1 & 14.6 & 15.6 & 15.6 & 14.5 & 13.2 & 12.8 & 13.2 & 13.5 \\
\hline United States & 8.8 & 9 & 8.8 & 8.5 & 8.2 & 7.7 & 7.4 & 7.6 & 7.5 \\
\hline OECD total & 19.4 & 20.1 & 19.7 & 19.4 & 19 & 18.3 & 17.6 & 17.3 & 16.9 \\
\hline
\end{tabular}


Table A2. Comparison of pension benefit levels between employee and the self-employed

Relative pension levels as a percentage of economy-wide average earnings, average earners

\begin{tabular}{|c|c|c|c|}
\hline & Employee (A) & Self-employed (B) & Difference $(A-B) / A$ \\
\hline Australia & 43.1 & 17.4 & $60 \%$ \\
\hline Austria & 80.1 & 80.1 & $0 \%$ \\
\hline Canada & 43.9 & 43.9 & $0 \%$ \\
\hline Czech & 49.1 & 39.4 & $20 \%$ \\
\hline Denmark & 75.8 & 29.2 & $61 \%$ \\
\hline Finland & 63.4 & 63.4 & $0 \%$ \\
\hline Germany & 39.9 & 39.9 & $0 \%$ \\
\hline Hungary & 76.9 & 76.9 & $0 \%$ \\
\hline Iceland & 77.5 & 77.5 & $0 \%$ \\
\hline Ireland & 32.5 & 32.5 & $0 \%$ \\
\hline Italy & 79.9 & 79.2 & $1 \%$ \\
\hline Japan & 34.4 & 13.4 & $61 \%$ \\
\hline Korea & 66.8 & 66.8 & $0 \%$ \\
\hline Luxembourg & 88.3 & 88.3 & $0 \%$ \\
\hline Mexico & 35.8 & 0 & $100 \%$ \\
\hline Netherlands & 81.9 & 31.2 & $62 \%$ \\
\hline New Zealand & 39.7 & 39.7 & $0 \%$ \\
\hline Norway & 60.7 & 60.7 & $0 \%$ \\
\hline Poland & 62.2 & 62.2 & $0 \%$ \\
\hline Portugal & 54.1 & 54.1 & $0 \%$ \\
\hline Slovak & 56.7 & 28.4 & $50 \%$ \\
\hline Spain & 88.7 & 84 & $5 \%$ \\
\hline Sweden & 62.1 & 52.7 & $15 \%$ \\
\hline Switzerland & 58.4 & 35.8 & $39 \%$ \\
\hline Turkey & 107.6 & 107.6 & $0 \%$ \\
\hline UK & 30.8 & 25.4 & $18 \%$ \\
\hline US & 41.2 & 41.2 & $0 \%$ \\
\hline Average & 60.43 & 50.77 & $18 \%$ \\
\hline
\end{tabular}

Note: 1 . The contribution period is 40 years for Italy and 35 years for Spain.

2. The year is 2004 , but 2003 for Italy and 2000 for Spain.

Source: OECD Pension Model except OECD (2004) for Italy, and Spain (2001) for Spain. 


\section{ANNEX 3}

\section{OVERVIEW OF PENSION RULES FOR DEPENDENT EMPLOYEES AND THE SELF- EMPLOYED (2004)}

* This overview is based on MISSOC (2004), Social Security Programs Throughout the World (various years) and various national sources.

\section{Australia}

Australia's pension system has two components: a means-tested age pension plus the superannuation guarantee, a compulsory contribution to a private pension plan. The self-employed can join the superannuation voluntarily.

\begin{tabular}{|c|c|c|c|c|}
\hline & Coverage & Contributions & Benefits & Note \\
\hline Employee & $\begin{array}{l}\text { Targeted: Residents. } \\
\text { Defined contribution } \\
\text { (superannuation): } \\
\text { Employed persons older } \\
\text { than age } 17 \text { and younger } \\
\text { than age } 70 \text { earnings more } \\
\text { than AUD } 450 \text { a month. }\end{array}$ & $\begin{array}{l}\text { Targeted: None (tax- } \\
\text { financed). } \\
\text { Defined contribution } \\
\text { (superannuation): } \\
9 \% \text { of basic wages } \\
\text { by employer. } \\
\text { Contributions by } \\
\text { employees are not } \\
\text { compulsory. }\end{array}$ & $\begin{array}{l}\text { Targeted: Up to } \\
\text { AUD464.20 every } 2 \\
\text { weeks for a single } \\
\text { person. } \\
\text { Defined contribution: } \\
\text { The accumulated } \\
\text { capital is converted } \\
\text { into a price-indexed } \\
\text { annuity. }\end{array}$ & \\
\hline Self-employed & $\begin{array}{l}\text { Targeted: Residents. } \\
\text { Defined contribution } \\
\text { (superannuation): Voluntary } \\
\text { participation. }\end{array}$ & $\begin{array}{l}\text { Targeted: None (tax- } \\
\text { financed). } \\
\text { Defined contribution } \\
\text { (superannuation): } \\
\text { Voluntary } \\
\text { contributions with tax } \\
\text { deduction. There is } \\
\text { no upper limit for the } \\
\text { contributions. }\end{array}$ & $\begin{array}{l}\text { Targeted: Up to } \\
\text { AUD464.20 every } 2 \\
\text { weeks for a single } \\
\text { person. } \\
\text { Defined contribution: } \\
\text { - }\end{array}$ & $\begin{array}{l}\text { As of September } \\
2003 \text {, there are } \\
275,523 \text { small funds } \\
\text { for the self- } \\
\text { employed. The } \\
\text { number is } 511000 \\
\text { and takes } 2 \% \text { of } \\
\text { total superannuation } \\
\text { members (In } 2003 \text {, } \\
\text { the self-employment } \\
\text { rate is } 13.4 \% \text { of total } \\
\text { civilian } \\
\text { employment). }\end{array}$ \\
\hline
\end{tabular}




\section{Austria}

Separate special schemes for farmers, and craftsmen and retailers have been integrated recently (from 2005). The pension scheme is mainly earnings-related.

\begin{tabular}{|c|c|c|c|c|}
\hline & Coverage & Contributions & Benefits & Note \\
\hline Employee & $\begin{array}{l}\text { Wage earners and } \\
\text { salaried employees } \\
\text { (separate systems with } \\
\text { essentially identical } \\
\text { provisions) earning } \\
€ 316.54 \text { or more a } \\
\text { month and apprentices. }\end{array}$ & $\begin{array}{l}22.8 \% \text { of earnings } \\
\text { (10.25\% by } \\
\text { employee and } \\
12.55 \% \text { by } \\
\text { employer). }\end{array}$ & $\begin{array}{l}\text { DB. } \\
\text { The current } \\
\text { accrual rate is } 2 \% \\
\text { of earnings for } \\
\text { each year of } \\
\text { contributions, but } \\
\text { this will fall } \\
\text { gradually. }\end{array}$ & $\begin{array}{l}\text { Individual separate } \\
\text { schemes for } \\
\text { mining, railways } \\
\text { and notaries. } \\
\text { The proportion of } \\
\text { tax-based financing } \\
\text { (government } \\
\text { subsidy) is about } \\
15 \%(2002) \text {. }\end{array}$ \\
\hline \multirow[t]{2}{*}{ Self-employed } & $\begin{array}{l}\text { Farmers: Compulsory } \\
\text { for farm owners and } \\
\text { assisting family } \\
\text { members. }\end{array}$ & $\begin{array}{l}22.8 \% \text { ( } 15 \% \text { by } \\
\text { farmers' own } \\
\text { "personal } \\
\text { contributions" and } \\
7.8 \% \text { of } \\
\text { government's } \\
\text { "partner co- } \\
\text { payment"). }\end{array}$ & $\begin{array}{l}\text { Benefits rules are } \\
\text { the same as } \\
\text { those of } \\
\text { employee. }\end{array}$ & $\begin{array}{l}\text { The proportion of } \\
\text { tax-based financing } \\
\text { (government } \\
\text { subsidy) is about } \\
74 \%(2001) .\end{array}$ \\
\hline & $\begin{array}{l}\text { The self-employed in } \\
\text { trade and business: } \\
\text { Craftsmen and retailers. } \\
\text { Other professional } \\
\text { workers such as } \\
\text { doctors, lawyers, } \\
\text { pharmacists, etc. Since } \\
\text { 1998, freelancers and } \\
\text { related workers whose } \\
\text { jobs do not require a } \\
\text { trade or business } \\
\text { license have been } \\
\text { subject to compulsory } \\
\text { pension. }\end{array}$ & $\begin{array}{l}22.8 \% \text { ( } 17.5 \% \text { by } \\
\text { the self-employed' } \\
\text { own "personal } \\
\text { contributions" and } \\
5.3 \% \text { of } \\
\text { government's } \\
\text { "partner co- } \\
\text { payment"). }\end{array}$ & $\begin{array}{l}\text { Benefits rules are } \\
\text { the same as } \\
\text { those of } \\
\text { employee. }\end{array}$ & $\begin{array}{l}\text { The proportion of } \\
\text { tax-based financing } \\
\text { (government } \\
\text { subsidy) is about } \\
41 \%(2001) \text {. }\end{array}$ \\
\hline
\end{tabular}




\section{Belgium}

There are three pension schemes: employee (special provisions for miners and seamen), the selfemployed and civil servants. The pension system is mainly earnings-related.

\begin{tabular}{|c|c|c|c|c|}
\hline & Coverage & Contributions & Benefits & Note \\
\hline Employee & Employed persons & $\begin{array}{l}16.36 \% \text { ( } 7.5 \% \text { of earnings } \\
\text { by employee and } 8.86 \% \\
\text { of payroll by employer). }\end{array}$ & $\begin{array}{l}\text { DB. } \\
\text { The full replacement } \\
\text { rate for a single } \\
\text { pensioner is } 60 \% \text {. }\end{array}$ & \\
\hline Self-employed & $\begin{array}{l}\text { Compulsory for the self- } \\
\text { employed and voluntary } \\
\text { for the assisting spouse. }\end{array}$ & $\begin{array}{l}\text { Up to } € 9,067.99, € 445.47 \\
\text { per quarter. Between } \\
€ 9,067.99 \text { and } 44,289.23 \text {, } \\
19.65 \% \text { of net } \\
\text { professional income. } \\
\text { Between } € 44,289.23 \text { and } \\
€ 65,273.48,14.16 \% \text { of } \\
\text { net professional income. } \\
\text { More than } € 65,273.48 \text {, } \\
€ 0 .\end{array}$ & $\begin{array}{l}\text { There are differences } \\
\text { between the } \\
\text { employee's scheme } \\
\text { and the self-employed' } \\
\text { scheme as to the way } \\
\text { to calculate a pension. }\end{array}$ & $\begin{array}{l}\text { The benefit } \\
\text { calculation } \\
\text { based on real } \\
\text { wage is } \\
\text { subject to a } \\
\text { correction. } \\
\text { The } \\
\text { correction } \\
\text { uses a } \\
\text { coefficient, } \\
\text { expressing } \\
\text { the ratio of } \\
\text { the self- } \\
\text { employed } \\
\text { contribution to } \\
\text { the salaried } \\
\text { worker's } \\
\text { contribution. }\end{array}$ \\
\hline
\end{tabular}




\section{Canada}

Canadian pension consists of a basic pension scheme which can be topped up with an income-tested targeted pension, and an earnings-related Canadian Pension Plan (or Quebec Pension Plan).

\begin{tabular}{|c|c|c|c|c|}
\hline & Coverage & Contributions & Benefits & Note \\
\hline Employee & $\begin{array}{l}\text { Basic: Residents. } \\
\text { Earnings-related: All } \\
\text { employees working in } \\
\text { Canada. But those in } \\
\text { casual employment } \\
\text { (annual earnings less } \\
\text { than CAD 3,500) or in } \\
\text { seasonal agricultural } \\
\text { employment are } \\
\text { excluded. }\end{array}$ & $\begin{array}{l}\text { Basic: None. } \\
\text { Earnings-related: } 9.9 \% \\
\text { ( } 4.95 \% \text { of earnings by } \\
\text { employee and } 4.95 \% \text { of } \\
\text { earnings by employer). }\end{array}$ & $\begin{array}{l}\text { Basic: The maximum } \\
\text { monthly pension is } \\
\text { CAD461.55. } \\
\\
\text { Earnings-related: DB } \\
25 \% \text { of average } \\
\text { adjusted yearly } \\
\text { covered earnings. }\end{array}$ & \\
\hline Self-employed & $\begin{array}{l}\text { Basic: Residents. } \\
\text { Earnings-related: All self- } \\
\text { employed persons } \\
\text { residing in Canada. }\end{array}$ & $\begin{array}{l}\text { Basic: None. } \\
\text { Earnings-related: } \\
9.9 \% \text { of net business } \\
\text { income (after expenses). }\end{array}$ & $\begin{array}{l}\text { The same as that of } \\
\text { employee. }\end{array}$ & \\
\hline
\end{tabular}




\section{Czech Republic}

The Czech social security system is in principle uniform for employees and the self-employed. The current system was established in 1990 by adopting the definition of the self-employed (until then farmers, people providing services under a special license issued by local government and artists) and the contribution payment (until then, only farmers paid contributions).

\begin{tabular}{|c|c|c|c|c|}
\hline & Coverage & Contributions & Benefits & Note \\
\hline Employee & $\begin{array}{l}\text { Employees, members } \\
\text { of assimilated groups } \\
\text { (such as students, } \\
\text { persons caring for } \\
\text { children etc.) }\end{array}$ & $\begin{array}{l}28 \% \text { of gross salary } \\
\text { ( } 6.5 \% \text { by employee } \\
\text { and } 21.5 \% \text { by } \\
\text { employer). No ceiling. }\end{array}$ & $\begin{array}{l}\text { DB. } \\
\text { A flat-rate basic amount } \\
\text { plus an earnings-related } \\
\text { percentage amount } \\
\text { based on the personal } \\
\text { assessment base and } \\
\text { the number of years of } \\
\text { insurance. }\end{array}$ & \\
\hline Self-employed & $\begin{array}{l}\text { Compulsory for all self- } \\
\text { employed persons. }\end{array}$ & $\begin{array}{l}28 \% \text { of declared } \\
\text { earnings (declared } \\
\text { earnings }=50 \% \text { of } \\
\text { difference between } \\
\text { income and } \\
\text { expenses). Ceiling is } \\
\text { CZK } 486000 \text { per } \\
\text { year. }\end{array}$ & $\begin{array}{l}\text { Pensions are calculated } \\
\text { according to the rules for } \\
\text { employee. }\end{array}$ & $\begin{array}{l}\text { Number of insured } \\
\text { (1999): } 610,105 \\
\text { (total } 4,727,184) \text {, } \\
12.9 \% \text { of total } \\
\text { insured. } \\
\text { The self- } \\
\text { employment rate is } \\
14.5 \% \text { in } 1999 .\end{array}$ \\
\hline
\end{tabular}




\section{Denmark}

In general, the Danish social protection system does not operate on the principle of distinction between the employed and the self-employed.

\begin{tabular}{|c|c|c|c|c|}
\hline & Coverage & Contributions & Benefits & Note \\
\hline Employee & $\begin{array}{l}\text { Basic: All resident } \\
\text { citizens. } \\
\text { ATP scheme: Employees } \\
\text { aged } 16 \text { to } 66 \text { if working } \\
\text { time exceeds } 9 \text { hours a } \\
\text { week. } \\
\text { Defined contribution } \\
(S P) \text { : Employees aged } 16 \\
\text { to } 66 \text { (69 from July 2004) } \\
\text { Occupational: Nearly } \\
\text { universal (based on } \\
\text { agreement between } \\
\text { social partners). }\end{array}$ & $\begin{array}{l}\text { Basic: None (tax- } \\
\text { financed). } \\
\text { ATP scheme: The } \\
\text { contribution amount } \\
\text { depends on the } \\
\text { number of hours } \\
\text { worked (1/3 } \\
\text { employee, } 2 / 3 \\
\text { employer). } \\
\text { Defined contribution } \\
\text { (SP): } 1 \% \text { of gross- } \\
\text { income } \\
\text { Occupational: } 15 \% \\
\text { (employer } 10 \% \text {, } \\
\text { employee } 5 \% \text { ). }\end{array}$ & $\begin{array}{l}\text { Basic: DKK 4,648 a } \\
\text { month. } \\
\text { ATP Scheme: Pension } \\
\text { depends on contribution } \\
\text { record. } \\
\text { Defined contribution } \\
(S P) \text { : Pension depends } \\
\text { on contribution record. } \\
\text { Occupational: - }\end{array}$ & \\
\hline Self-employed & $\begin{array}{l}\text { Basic: All resident } \\
\text { citizens. } \\
\text { ATP Scheme: Voluntary } \\
\text { for the self-employed. } \\
\text { Defined contribution } \\
(S P) \text { : Compulsory for the } \\
\text { self-employed. } \\
\text { Occupational: - }\end{array}$ & $\begin{array}{l}\text { Basic: None (tax- } \\
\text { financed). } \\
\text { ATP Scheme: None } \\
\text { (voluntary). } \\
\text { Defined contribution } \\
(S P): 1 \% \text { of gross } \\
\text { income. } \\
\text { Occupational: - }\end{array}$ & $\begin{array}{l}\text { Except for ATP scheme } \\
\text { and occupational } \\
\text { pension, pensions are } \\
\text { calculated according to } \\
\text { the rules for employee. }\end{array}$ & \\
\hline
\end{tabular}

Note. $\quad$ The ATP scheme is a special insurance system for the employed. The self-employed have access only if, after exercising a salaried activity with a minimum of three years of contributions, they have voluntarily opted to continue the insurance. Of the pension amount of the average-wage worker, the ATP scheme takes $1 / 10$. If the self-employed do not join the ATP, he/she, on average, would obtain pension amount $1 / 10$ less than that of employee. 


\section{Finland}

The self-employed and the employed persons have, more or less, the same coverage for pension benefits. There special pension schemes for farmers, and the self-employed. Each has its own act: Selfemployed Persons' Pensions Act (YEL) and Farmers' Pensions Act (MYEL).

\begin{tabular}{|c|c|c|c|c|c|}
\hline & & Coverage & Contributions & Benefits & Note \\
\hline \multicolumn{2}{|l|}{ Employee } & $\begin{array}{l}\text { Targeted (means-tested): } \\
\text { All Finnish citizens. } \\
\text { Earnings-related: All regular } \\
\text { employees aged } 14 \text { or older } \\
\text { (From } 2005, \text { persons caring } \\
\text { for a child under age } 3 \text { and } \\
\text { students who received a } \\
\text { degree, for study periods up } \\
\text { to a maximum of } 5 \text { years) }\end{array}$ & $\begin{array}{l}\text { Targeted: None by } \\
\text { employee. } \\
\text { Earnings-related: } 4.6 \% \text { of } \\
\text { earnings by employee. } \\
21.59 \% \text { for employer with } \\
\text { fewer than } 50 \\
\text { employees. For employer } \\
\text { with more than } 50 \\
\text { employees, } 16.9 \% \text { to } \\
24.0 \% \text { according to the } \\
\text { age of the employee. The } \\
\text { average contribution is } \\
21.4 \% \text {. }\end{array}$ & $\begin{array}{l}\text { Targeted: } \\
€ 11.21 \text { to } \\
€ 496.38 \text {. } \\
\text { Earnings- } \\
\text { related: } 1.5 \% \\
\text { of average } \\
\text { pensionable } \\
\text { earnings for } \\
\text { each year of } \\
\text { employment } \\
\text { between ages } \\
23 \text { and } 59 .\end{array}$ & \\
\hline \multirow[t]{2}{*}{$\begin{array}{l}\text { Self- } \\
\text { employed }\end{array}$} & Farmers & $\begin{array}{l}\text { Targeted (means-tested): } \\
\text { All Finnish citizens. } \\
\text { Earnings-related: } \\
\text { Compulsory for farmers, } \\
\text { fishermen and reindeer } \\
\text { herders when the farm } \\
\text { contains more than } 5 \text { ha of } \\
\text { arable land and the income } \\
\text { is at least } € 2,752.04 \text { a year } \\
(2004) \text {. }\end{array}$ & $\begin{array}{l}\text { Targeted: None. } \\
\text { Earnings-related: } 21.4 \% \\
\text { of declared earnings (In } \\
\text { reality, due to deduction, } \\
\text { on average } 10.5 \% \text { of } \\
\text { declared earnings). }\end{array}$ & $\begin{array}{l}\text { Basic } \\
\text { entitlements } \\
\text { and benefits } \\
\text { are similar to } \\
\text { those of } \\
\text { employee. }\end{array}$ & $\begin{array}{l}\text { In } 2002,76 \% \\
\text { of total } \\
\text { finance is } \\
\text { supported by } \\
\text { the } \\
\text { government. }\end{array}$ \\
\hline & $\begin{array}{l}\text { The self- } \\
\text { employed }\end{array}$ & $\begin{array}{l}\text { Targeted (means-tested): } \\
\text { All Finnish citizens. } \\
\text { Earnings-related: The self- } \\
\text { employment has lasted } \\
\text { continuously for at least four } \\
\text { months since the age of } 18 \\
\text { and annual earnings from } \\
\text { self-employment amount to } \\
\text { a minimum of } € 5,504.14 \\
\text { (2004). Professionals such } \\
\text { as doctors, lawyers, writers } \\
\text { and freelance journalists } \\
\text { are also covered. }\end{array}$ & $\begin{array}{l}\text { Targeted: None. } \\
\text { Earnings-related: } \\
21.4 \% \text { of declared } \\
\text { earnings ( } 16.05 \% \text { for the } \\
\text { first } 4 \text { years of self- } \\
\text { employment). }\end{array}$ & $\begin{array}{l}\text { Basic } \\
\text { entitlements } \\
\text { and benefits } \\
\text { are similar to } \\
\text { those of } \\
\text { employee. }\end{array}$ & $\begin{array}{l}\text { In } 2002,8 \% \\
\text { of total } \\
\text { finance is } \\
\text { supported by } \\
\text { the } \\
\text { government. }\end{array}$ \\
\hline
\end{tabular}




\section{France}

Social protection for the self-employed is subject to specific regulations. Farmers and other selfemployed have their own social security schemes such as Mutual Insurance Fund for Farmers.

\begin{tabular}{|c|c|c|c|c|c|}
\hline & & Coverage & Contributions & Benefits & Note \\
\hline \multicolumn{2}{|l|}{ Employee } & $\begin{array}{l}\text { Earnings-related: employed } \\
\text { persons. } \\
\text { Mandatory occupational: } \\
\text { ARRCO for non-executive } \\
\text { private workers and AGIRC for } \\
\text { executive private workers. }\end{array}$ & $\begin{array}{l}\text { Earnings-related: } 6.55 \% \\
\text { of insurable earnings by } \\
\text { employee and } 8.2 \% \text { of } \\
\text { insurable earnings by } \\
\text { employer. } \\
\text { Mandatory occupational: } \\
3-7.5 \% \text { by employee and } \\
4.5-12.5 \% \text { by employer. }\end{array}$ & $\begin{array}{l}\text { Earnings-related: } \\
\text { DB. } \\
\text { After a full career, } \\
50 \% \text { of replacement } \\
\text { rate. } \\
\text { Mandatory } \\
\text { occupational: Points } \\
\text { system. }\end{array}$ & \\
\hline \multirow[t]{2}{*}{$\begin{array}{l}\text { Self- } \\
\text { employed }\end{array}$} & Farmers & $\begin{array}{l}\text { Compulsory for the head } \\
\text { farmer, farm associates and } \\
\text { family members who take part } \\
\text { in the farm. }\end{array}$ & $\begin{array}{l}\text { Earnings-related: Main } \\
\text { part (for benefits) is } \\
8.44 \% \text { within the limit of } \\
\text { the social security ceiling, } \\
1.29 \% \text { on professional } \\
\text { income. Additional part } \\
\text { (for management costs) } \\
\text { is } 2.53 \% \text {, of which } 0.25 \% \\
\text { on professional income. } \\
\text { Mandatory occupational: } \\
2.97 \% \text { of occupational } \\
\text { income. }\end{array}$ & $\begin{array}{l}\text { Earnings-related: } \mathrm{A} \\
\text { flat-rate maximum } \\
\text { pension of } € \\
2,898.28 \text { a year for } \\
\text { the maximum } \\
\text { length requested } \\
\text { depending on the } \\
\text { birth year of the } \\
\text { insured person, and } \\
\text { a proportional } \\
\text { pension calculated } \\
\text { by points (Minimum } \\
\text { guaranteed for a } \\
\text { complete career is } \\
€ 7,052.95 \text { per } \\
\text { year). } \\
\text { Mandatory } \\
\text { occupational: } \\
\text { Calculated by } \\
\text { points. }\end{array}$ & \\
\hline & $\begin{array}{l}\text { The self- } \\
\text { employed }\end{array}$ & $\begin{array}{l}\text { Four schemes exist: Liberal } \\
\text { professions (CNAVPL), } \\
\text { Lawyers (CNBF), Craftsmen } \\
\text { (CANCAVA) and shopkeepers } \\
\text { \& manufacturers (ORGANIC). } \\
\text { Workers practising a self- } \\
\text { employed activity must be } \\
\text { registered with social } \\
\text { insurance organisations and } \\
\text { pay their contributions. } \\
\text { Compulsory affiliation for } \\
\text { managers of firms on the } \\
\text { trades register as well as } \\
\text { assisting family members who } \\
\text { take part in the small-scale } \\
\text { enterprise, and persons } \\
\text { practising an industrial and } \\
\text { commercial activity involving } \\
\text { signing up on the Commercial } \\
\text { Register or liability to } \\
\text { professional tax as a retailer. }\end{array}$ & $\begin{array}{l}\text { Earnings-related: } 16.35 \% \\
\text { of the professional } \\
\text { income within the limit of } \\
\text { the social security ceiling. } \\
\text { Mandatory occupational: } \\
6.7 \% \text {. }\end{array}$ & $\begin{array}{l}\text { The general rules } \\
\text { for earnings-related } \\
\text { scheme are } \\
\text { identical to those of } \\
\text { employees. }\end{array}$ & \\
\hline
\end{tabular}

Note. Financial equalisation mechanisms exist between these different schemes. 


\section{Germany}

Self-employed craftsmen are covered within the scope of the general scheme (for employee). Farmers including assisting family members have independent social security systems.

\begin{tabular}{|c|c|c|c|c|c|}
\hline & & Coverage & Contributions & Benefits & Note \\
\hline \multicolumn{2}{|l|}{ Employee } & $\begin{array}{l}\text { Earnings-related: } \\
\text { Employee (including } \\
\text { apprentices), certain } \\
\text { self-employed persons } \\
\text { (craftsmen and } \\
\text { journalists), persons } \\
\text { caring for a child under } \\
\text { age 3, recipients of } \\
\text { social benefits. }\end{array}$ & $\begin{array}{l}\text { Earnings-related: } 19.5 \% \\
(9.75 \% \text { of earnings by } \\
\text { employee, none if } \\
\text { earnings are below } € 400 \\
\text { a month, and } 9.75 \% \text { of } \\
\text { payroll by employer, } 12 \% \\
\text { of earnings for employee } \\
\text { with monthly earnings } \\
\text { below } € 400) \text {. }\end{array}$ & $\begin{array}{l}\text { The total of } \\
\text { individual } \\
\text { earnings points } \\
\text { multiplied by the } \\
\text { pension factor of } \\
1.0 \text { and the } \\
\text { pension value. } \\
45.8 \% \text { of average } \\
\text { earnings. }\end{array}$ & $\begin{array}{l}\text { Optional for } \\
\text { retailers. }\end{array}$ \\
\hline \multirow[t]{2}{*}{$\begin{array}{l}\text { Self- } \\
\text { employed }\end{array}$} & Farmers & $\begin{array}{l}\text { Compulsory for the } \\
\text { farmers and their } \\
\text { spouses. }\end{array}$ & $\begin{array}{l}\text { n.a. } \\
\text { Average contributions } \\
\text { amount to less than half } \\
\text { of those from employee's } \\
\text { scheme. }\end{array}$ & $\begin{array}{l}\text { Average benefits } \\
\text { amount to less } \\
\text { than half of those } \\
\text { from employee's } \\
\text { scheme. }\end{array}$ & $\begin{array}{l}\text { Among total } \\
\text { finance, } 75 \% \\
\text { is from tax } \\
\text { revenues and } \\
25 \% \text { from flat- } \\
\text { rate } \\
\text { contributions. }\end{array}$ \\
\hline & $\begin{array}{l}\text { The self- } \\
\text { employed }\end{array}$ & $\begin{array}{l}\text { Voluntary for retailers. } \\
\text { Various schemes for } \\
\text { professionals organised } \\
\text { in professional } \\
\text { chambers, such as } \\
\text { doctors, lawyers and } \\
\text { architects. Compulsory } \\
\text { for those self-employed } \\
\text { who are members of } \\
\text { the respective } \\
\text { chambers. }\end{array}$ & $19.5 \%$ of income. & $\begin{array}{l}\text { Benefits are paid } \\
\text { according to the } \\
\text { regulation of the } \\
\text { employee's } \\
\text { scheme. }\end{array}$ & $\begin{array}{l}\text { These } \\
\text { schemes are } \\
\text { run by } \\
\text { decentralised } \\
\text { private } \\
\text { institutions. }\end{array}$ \\
\hline
\end{tabular}

Note.

1) Coverage has been extended, but there is no general, universal coverage of the whole population. Part of the self-employed are excluded from the public scheme and have to rely on private provision.

2) Self-employed artists and members of the publishing professions have to pay contributions under the Artists Social Welfare Act, if their annual income exceeds a set minimum, $€ 3,900$ a year and until they have been five years in the profession - though they pay only half the contributions themselves. The Artists' Social Welfare Fund decides who must pay contributions and also sets the rate. 


\section{Greece}

In 1998, a basic social security system (OGA) for farmers was introduced, strictly contributory. From 1999, a process for the integration of three main insurance funds for the self-employed - TEBE (craftsmen and other professionals), TAE (retailers), TSA (motorists) - into a single unit called OAEE started.

\begin{tabular}{|c|c|c|c|c|c|}
\hline & Coverage & Contributions & Benefits & Note \\
\hline \multicolumn{2}{|l|}{ Employee } & $\begin{array}{l}\text { Earnings-related: } \\
\text { Employees } \\
\text { in industry, commerce } \\
\text { and } \\
\text { related occupations } \\
\text { (IKA). }\end{array}$ & $\begin{array}{l}20 \% \text { of earnings } \\
\text { (6.67\% by } \\
\text { employee and } \\
13.33 \% \text { by } \\
\text { employer). }\end{array}$ & $\begin{array}{l}\text { Earnings-related: DB } \\
\text { scheme. }\end{array}$ & \\
\hline \multirow[t]{2}{*}{$\begin{array}{l}\text { Self- } \\
\text { employed }\end{array}$} & $\begin{array}{l}\text { Self- } \\
\text { employed }\end{array}$ & $\begin{array}{l}\text { Craftsmen, retailers } \\
\text { and motorists (OAEE). } \\
\text { Family members are } \\
\text { co-insured and } \\
\text { exempt from } \\
\text { contributions. }\end{array}$ & $20 \%$ of earnings. & $\begin{array}{l}\text { Nearly identical to } \\
\text { that of employees. } \\
\text { But, earnings base is } \\
\text { lifetime average } \\
\text { earnings (employee: } \\
\text { the last } 5 \text { years } \\
\text { salary). }\end{array}$ & \\
\hline & Farmers & $\begin{array}{l}\text { Farmers, employed } \\
\text { persons in agriculture } \\
\text { and fishermen (OGA). } \\
\text { This system applies to } \\
\text { all other self- } \\
\text { employed persons in } \\
\text { areas of less than } \\
5,000 \text { inhabitants and } \\
\text { in cities of less than } \\
2,000 \text { inhabitants, with } \\
\text { the exception of } \\
\text { persons insured under } \\
\text { the general scheme. } \\
\text { Family members are } \\
\text { con-insured and are } \\
\text { exempt from } \\
\text { contributions. }\end{array}$ & $\begin{array}{l}\text { n/a } \\
\text { Among total } \\
\text { finance, one third by } \\
\text { the insured and two } \\
\text { thirds by the } \\
\text { government under } \\
\text { the new system } \\
\text { from } 1998 \text {. }\end{array}$ & $\mathrm{n} / \mathrm{a}$ & $\begin{array}{l}\text { Under the old } \\
\text { system, farmers } \\
\text { did not make } \\
\text { contributions to } \\
\text { earnings-related } \\
\text { scheme (main } \\
\text { component). }\end{array}$ \\
\hline
\end{tabular}

Note. There are earmarked taxes for financing of pension funds for professionals. For example, the lawyers' fund receives a percentage from all contracts, the doctors' fund $4.6 \%$ of the wholesale price of pharmaceuticals. 


\section{Hungary}

All self-employed persons are covered for social security in the general system.

\begin{tabular}{|c|c|c|c|c|}
\hline & Coverage & Contributions & Benefits & Note \\
\hline Employee & $\begin{array}{l}\text { Earnings-related and } \\
\text { Defined contribution: } \\
\text { Employees, members of } \\
\text { handicraft and } \\
\text { agricultural cooperatives, } \\
\text { apprentices of } \\
\text { professional training } \\
\text { schools, outside workers, } \\
\text { artistic performers, } \\
\text { lawyers, public notaries, } \\
\text { the clergy, and recipients } \\
\text { of unemployment } \\
\text { benefits. }\end{array}$ & $\begin{array}{l}\text { Earnings related and } \\
\text { defined contribution: } \\
26.5 \% \text { ( } 8.5 \% \text { of } \\
\text { gross earnings by } \\
\text { employee and } 18 \% \\
\text { of payroll by } \\
\text { employer). }\end{array}$ & $\begin{array}{l}\text { Earnings related: } 53 \% \text { of } \\
\text { average earnings is paid } \\
\text { with } 20 \text { years of service. } \\
\text { Defined contribution: The } \\
\text { value of accumulated } \\
\text { contributions plus } \\
\text { accrued interest. }\end{array}$ & \\
\hline Self-employed & $\begin{array}{l}\text { Earnings-related and } \\
\text { Defined contribution: } \\
\text { Self-employed } \\
\text { entrepreneurs except } \\
\text { independent farmers. }\end{array}$ & $\begin{array}{l}\text { Earnings related and } \\
\text { defined contribution: } \\
\text { Equal to the total } \\
\text { employee and } \\
\text { employer } \\
\text { contribution. The } \\
\text { contribution base is } \\
\text { the income which } \\
\text { the self-employed } \\
\text { declare. }\end{array}$ & $\begin{array}{l}\text { The same calculation } \\
\text { method as that of } \\
\text { employee is applied. }\end{array}$ & \\
\hline
\end{tabular}

Note. The Hungarian pension system includes both employees and the self-employed. Only farmers are excluded. They can join on a voluntary basis. 


\section{Iceland}

One general scheme covers employees and the self-employed. There is no distinction between employee and the self-employed.

\begin{tabular}{|c|c|c|c|c|}
\hline & Coverage & Contributions & Benefits & Note \\
\hline Employee & $\begin{array}{l}\text { Targeted: All residents. } \\
\text { Mandatory occupational: } \\
\text { All employees. }\end{array}$ & $\begin{array}{l}\text { Targeted: None } \\
\text { (5.64\% by } \\
\text { employer). } \\
\text { Mandatory } \\
\text { occupational: } 10 \% \\
\text { of wages ( } 4 \% \text { by } \\
\text { employee and } 6 \% \\
\text { by employer). }\end{array}$ & $\begin{array}{l}\text { Targeted: ISK } 21,249 \text { a } \\
\text { month for a single } \\
\text { pensioner. } \\
\text { Mandatory occupational: } \\
1.4 \% \text { of average lifetime } \\
\text { salary per contribution } \\
\text { year. }\end{array}$ & \\
\hline Self-employed & $\begin{array}{l}\text { Targeted: All residents. } \\
\text { Mandatory occupational: } \\
\text { All self-employed } \\
\text { persons (including } \\
\text { farmers). }\end{array}$ & $\begin{array}{l}\text { Targeted: } 5.64 \% \text { of } \\
\text { the presumptive } \\
\text { income } \\
\text { (Presumptive } \\
\text { income is } \\
\text { employment income } \\
\text { comparable with the } \\
\text { remuneration one } \\
\text { would receive if } \\
\text { similarly employed } \\
\text { by an unrelated } \\
\text { person). } \\
\text { Mandatory } \\
\text { occupational: } 10 \% \\
\text { of earnings. }\end{array}$ & $\begin{array}{l}\text { The same rules as that } \\
\text { of employee are applied. }\end{array}$ & \\
\hline
\end{tabular}




\section{Ireland}

One general scheme covers employees and the self-employed.

\begin{tabular}{|c|c|c|c|c|}
\hline & Coverage & Contributions & Benefits & Note \\
\hline Employee & $\begin{array}{l}\text { Basic: Employed persons } \\
\text { aged } 16 \text { to } 65 \text { with } € 38 \\
\text { or more in weekly } \\
\text { covered earnings. }\end{array}$ & $\begin{array}{l}\text { Basic: For weekly } \\
\text { earnings of } € 356 \text { or } \\
\text { less, no contribution for } \\
\text { the first } € 127 \text { and } 4 \% \\
\text { for the remaining } \\
\text { balance. For weekly } \\
\text { earnings of } € 356 \text { or } \\
\text { more, } 2 \% \text { for the first } \\
€ 127 \text { and } 6 \% \text { for the } \\
\text { remaining balance } \\
\text { ( } 8.5 \% \text { or } 10.75 \% \text { by } \\
\text { employer according to } \\
\text { their earnings). }\end{array}$ & $\begin{array}{l}\text { The maximum } \\
\text { pension is } € 167.39 \text { a } \\
\text { week. }\end{array}$ & Global contribution \\
\hline Self-employed & $\begin{array}{l}\text { Basic: Self-employed } \\
\text { persons with annual } \\
\text { earnings of } € 3,174 \text { or } \\
\text { more (including farmers). }\end{array}$ & $\begin{array}{l}\text { For annual income of } \\
€ 18,512 \text { or less, } 3 \% \text { of } \\
\text { gross income; for } \\
\text { annual income greater } \\
\text { than } € 18,512,5 \% \text { of } \\
\text { gross income. }\end{array}$ & $\begin{array}{l}\text { The same rule as that } \\
\text { of employee is } \\
\text { applied. }\end{array}$ & Global contribution \\
\hline
\end{tabular}


DELSA/ELSA/WD/SEM(2009)12

\section{Italy}

A separate scheme for the self-employed exists.

\begin{tabular}{|c|c|c|c|c|}
\hline & Coverage & Contributions & Benefits & Note \\
\hline Employee & $\begin{array}{l}\text { Earnings-related: } \\
\text { Employed persons } \\
\text { including domestic } \\
\text { workers. }\end{array}$ & $\begin{array}{l}\text { Earnings-related: } \\
32.7 \%(8.89 \% \text { by } \\
\text { employee and } \\
23.81 \% \text { by employer). }\end{array}$ & $\begin{array}{l}\text { The resulting sum of annual } \\
\text { contributions, or "notional } \\
\text { capital" is multiplied by a } \\
\text { "transformation coefficient" at } \\
\text { retirement. This is the } \\
\text { corollary of the annuity rate } \\
\text { in a funded defined- } \\
\text { contribution scheme. }\end{array}$ & \\
\hline Self-employed & $\begin{array}{l}\text { Earnings-related: } \\
\text { Compulsory for } \\
\text { farmers, craftsmen and } \\
\text { retailers. It includes } \\
\text { free-lancers and other } \\
\text { semi-autonomous } \\
\text { workers, if not insured } \\
\text { in other pension funds. }\end{array}$ & $\begin{array}{l}\text { Earnings-related: } \\
19 \% \text { of professional } \\
\text { income. }\end{array}$ & $\begin{array}{l}\text { The contributions are paid } \\
\text { into the accounts for each } \\
\text { year of contributions, and are } \\
\text { reassessed at the end of the } \\
\text { year according to the GDP } \\
\text { five-year variation. The } \\
\text { resulting sum of annual } \\
\text { contributions, or "notional } \\
\text { capital" is multiplied by a } \\
\text { "transformation coefficient" at } \\
\text { retirement. }\end{array}$ & \\
\hline
\end{tabular}




\section{Japan}

Japanese basic pension scheme includes the self-employed (including farmers) and employee altogether. Compulsory earnings-related second tier scheme covers only employee, and the self-employed can join another second tier scheme for only them on a voluntary basis.

\begin{tabular}{|c|c|c|c|c|}
\hline & Coverage & Contributions & Benefits & Note \\
\hline Employee & $\begin{array}{l}\text { Basic: Residents age } 20 \\
\text { to } 59 . \\
\text { Earnings-related: } \\
\text { Employees of firms in } \\
\text { industry and commerce, } \\
\text { including seamen. }\end{array}$ & $\begin{array}{l}\text { Basic and Earnings- } \\
\text { related: } 13.58 \% \\
(6.79 \% \text { by employee } \\
\text { and } 6.79 \% \text { by } \\
\text { employer). } \\
14.96 \% \text { for miners } \\
\text { and seamen. }\end{array}$ & $\begin{array}{l}\text { Basic: } 794,500 \text { yen a } \\
\text { year for a fully insured } \\
\text { person. } \\
\text { Earnings-related: The } \\
\text { insured's indexed } \\
\text { average monthly wage } \\
\text { over the full career times } \\
\text { a coefficient determined } \\
\text { by the insured's date of } \\
\text { birth times the number of } \\
\text { months of coverage. }\end{array}$ & $\begin{array}{l}\text { Basic: Government } \\
\text { subsidy for one } \\
\text { third of the cost of } \\
\text { benefits plus } 100 \% \\
\text { of administrative } \\
\text { costs. } \\
\text { Earnings-related: } \\
\text { Government } \\
\text { subsidy for the } \\
\text { administration. } \\
\text {. }\end{array}$ \\
\hline Self-employed & $\begin{array}{l}\text { Basic: Residents age } 20 \\
\text { to } 59 \text { (The self-employed } \\
\text { and farmers). Low- } \\
\text { income persons are } \\
\text { exempt from paying the } \\
\text { contributions partially or } \\
\text { entirely. } \\
\text { Earnings-related: The } \\
\text { self-employed are } \\
\text { allowed to join the } \\
\text { separate scheme for } \\
\text { them (National Pension } \\
\text { Funds) voluntarily. Only } \\
\text { about } 4 \% \text { of the self- } \\
\text { employed are subscribing } \\
\text { to the Fund (0.77 million } \\
\text { out of } 22.37 \text { million } \\
\text { people). }\end{array}$ & $\begin{array}{l}\text { Basic: } 13,300 \text { yen a } \\
\text { month. } \\
\text { Earnings-related: } \\
\mathrm{n} / \mathrm{a}\end{array}$ & $\begin{array}{l}\text { Basic: The same as that } \\
\text { of employee's scheme. } \\
\text { Earnings-related: n/a }\end{array}$ & $\begin{array}{l}\text { Basic: Government } \\
\text { subsidy for one } \\
\text { third of the cost of } \\
\text { benefits plus } 100 \% \\
\text { of administrative } \\
\text { costs. }\end{array}$ \\
\hline
\end{tabular}




\section{Korea}

One earnings-related scheme covers both employees and the self-employed. There is no distinction between employee and the self-employed.

\begin{tabular}{|c|c|c|c|c|}
\hline & Coverage & Contributions & Benefits & Note \\
\hline Employee & $\begin{array}{l}\text { Employees between } \\
\text { ages } 18 \text { and } 59 .\end{array}$ & $\begin{array}{l}9 \% \text { of earnings } \\
\text { ( } 4.5 \% \text { by employee } \\
\text { and } 4.5 \% \text { by } \\
\text { employer). }\end{array}$ & $\begin{array}{l}\text { The basic monthly } \\
\text { pension amount (BPA) } \\
\text { plus } 5 \% \text { of the monthly } \\
\text { BPA for each year of } \\
\text { insurance beyond } 20 \\
\text { years. }\end{array}$ & \\
\hline Self-employed & $\begin{array}{l}\text { The self-employed } \\
\text { (including farmers and } \\
\text { fishermen) between ages } \\
18 \text { and } 59 .\end{array}$ & $\begin{array}{l}9 \% \text { of monthly } \\
\text { business earnings. }\end{array}$ & $\begin{array}{l}\text { The same rules as that } \\
\text { of employee are applied. }\end{array}$ & $\begin{array}{l}\text { Government } \\
\text { subsidy for farmer } \\
\text { and fishermen (no } \\
\text { less than } 1 / 3 \text { of the } \\
\text { contribution of the } \\
\text { lowest income } \\
\text { group). }\end{array}$ \\
\hline
\end{tabular}

Note. Many self-employed persons who have regular earnings are suspected of not joining the pension scheme. Even though it is difficult to estimate the exact degree of this evasion, it appears to account for a substantial proportion of the total self-employed. 


\section{Luxembourg}

Social protection for the self-employed is primarily covered under the rule of the general system. However, special organisations are responsible for matters for farmers on the one hand (Agricultural Pension Fund) and craftsmen, retailers and manufacturers on the other hand (Pension Fund for Craftsmen, Retailers and Manufacturers).

\begin{tabular}{|c|c|c|c|c|}
\hline & Coverage & Contributions & Benefits & Note \\
\hline Employee & $\begin{array}{l}\text { All economically active } \\
\text { persons in the private } \\
\text { and public sectors. }\end{array}$ & $\begin{array}{l}24 \% \text { of gross wage } \\
\text { ( } 8 \% \text { by employee, } 8 \% \\
\text { by employer and } 8 \% \\
\text { by the government). }\end{array}$ & $\begin{array}{l}\text { A flat-rate component of } \\
€ 329.75 \text { a month if } \\
\text { insured for } 40 \text { years and } \\
\text { an annual increment } \\
\text { equal to } 1.85 \% \text { of } \\
\text { adjusted lifetime covered } \\
\text { earnings. }\end{array}$ & \\
\hline Self-employed & $\begin{array}{l}\text { All economically active } \\
\text { self-employed persons } \\
\text { (including farmers). }\end{array}$ & $\begin{array}{l}24 \% \text { of professional } \\
\text { income ( } 16 \% \text { by the } \\
\text { self-employed and } 8 \% \\
\text { by the government). } \\
\text { For farmers, } \\
\text { contributions are } \\
\text { based on the farmland } \\
\text { size, nature of crops, } \\
\text { and vegetable and } \\
\text { animal productions. } \\
\text { Smaller farms are } \\
\text { subject to flat-rate } \\
\text { contributions. }\end{array}$ & $\begin{array}{l}\text { The same rules of those } \\
\text { of employee are applied. }\end{array}$ & \\
\hline
\end{tabular}


DELSA/ELSA/WD/SEM(2009)12

\section{Mexico}

Mexico's new funded scheme does not request the compulsory participation of the self-employed.

\begin{tabular}{|l|l|l|l|l|}
\hline & Coverage & Contributions & Benefits & Note \\
\hline Employee & $\begin{array}{l}\text { Funded scheme } \\
\text { (mandatory individual } \\
\text { accounts): All workers } \\
\text { entering the labour } \\
\text { force on or after } \\
\text { January 1, 1997. }\end{array}$ & $\begin{array}{l}6.275 \% \text { by employee } \\
\text { and employer. 0.225\% } \\
\text { by the government. }\end{array}$ & $\begin{array}{l}\text { Benefits are calculated } \\
\text { by the value of } \\
\text { accumulated capital plus } \\
\text { accrued interest. }\end{array}$ & \\
\hline Self-employed & $\begin{array}{l}\text { Voluntary. } \\
\text { n/a }\end{array}$ & n/a & & \\
\hline
\end{tabular}




\section{Netherlands}

The general social protection system is applied to all residents of the Netherlands as a rule.

\begin{tabular}{|c|c|c|c|c|}
\hline & Coverage & Contributions & Benefits & Note \\
\hline Employee & $\begin{array}{l}\text { Basic: All residents. } \\
\text { Quasi-mandatory } \\
\text { occupational: Mainly } \\
\text { employees } \\
\text { (Determined by } \\
\text { industrial-relations } \\
\text { agreements). }\end{array}$ & $\begin{array}{l}\text { Basic: } 17.9 \% \text { of } \\
\text { income by employee } \\
\text { (additional } 1.25 \% \text { for } \\
\text { the survivor pension). } \\
5.85 \% \text { of payroll by } \\
\text { employer (additional } \\
0.85 \% \text { for disability } \\
\text { and } 2.2 \% \text { of } \\
\text { supplement). } \\
\text { Quasi-mandatory } \\
\text { occupational: } \\
\text { Determined by } \\
\text { industrial-relations } \\
\text { agreements. }\end{array}$ & $\begin{array}{l}\text { Basic: } € 921.28 \text { for single } \\
\text { persons and } € 631.76 \text { for } \\
\text { couples (A third of } \\
\text { average earnings). } \\
\text { Quasi-mandatory } \\
\text { occupational: } 1.75 \% \text { of } \\
\text { those earnings for each } \\
\text { year of service or } 2.25 \% \\
\text { of accrual rate for each } \\
\text { year of service. }\end{array}$ & \\
\hline Self-employed & $\begin{array}{l}\text { Basic: All residents. } \\
\text { Quasi-mandatory } \\
\text { occupational: } \\
\text { Compulsory for some } \\
\text { self-employed } \\
\text { professions such as } \\
\text { doctors and lawyers. }\end{array}$ & $\begin{array}{l}\text { Basic: } 17.9 \% \text { of } \\
\text { income. Additional } \\
1.25 \% \text { for survivor } \\
\text { pension and } 8.8 \% \text { for } \\
\text { the disability pension. } \\
\\
\text { Quasi-mandatory } \\
\text { occupational: } n / a\end{array}$ & $\begin{array}{l}\text { Basic: The same as that } \\
\text { of employee. } \\
\text { Quasi-mandatory } \\
\text { occupational: n/a }\end{array}$ & \\
\hline
\end{tabular}




\section{DELSA/ELSA/WD/SEM(2009)12}

\section{New Zealand}

The only public pension is flat rate based on a residency test.

\begin{tabular}{|l|l|l|l|l|}
\hline & \multicolumn{1}{|c|}{ Coverage } & \multicolumn{1}{|c|}{ Contributions } & \multicolumn{1}{c|}{ Benefits } & Note \\
\hline Employee & Basic: All residents. & None. & $\begin{array}{l}\text { NZD 249.09 a week for a } \\
\text { single person living } \\
\text { alone or NZD 383.22 a } \\
\text { week for an aged } \\
\text { married couple. }\end{array}$ & \\
\hline Self-employed & Basic: All residents. & None. & $\begin{array}{l}\text { NZD 249.09 a week for a } \\
\text { single person living } \\
\text { alone or NZD 383.22 a } \\
\text { week for an aged } \\
\text { married couple. }\end{array}$ & \\
& & & & \\
\hline
\end{tabular}




\section{Norway}

All self-employed persons are compulsory members of the general scheme.

\begin{tabular}{|c|c|c|c|c|}
\hline & Coverage & Contributions & Benefits & Note \\
\hline Employee & $\begin{array}{l}\text { Basic: All residents. } \\
\text { Earnings-related: All } \\
\text { employed earnings } \\
\text { over the base amount } \\
\text { (NOK } 56,861 \text { ). }\end{array}$ & $\begin{array}{l}\text { Basic and earnings- } \\
\text { related: } 21.9 \%(7.8 \% \\
\text { of income by } \\
\text { employee and } 14.1 \% \\
\text { of payroll by } \\
\text { employer). }\end{array}$ & $\begin{array}{l}\text { Basic: Up to } 100 \% \text { of the } \\
\text { base amount for single, } \\
150 \% \text { for couple. } \\
\text { Earnings-related: } 42 \% \text { of } \\
\text { the current base amount } \\
\text { multiplied by the } \\
\text { insured's average annual } \\
\text { number of pension } \\
\text { points in the } 20 \text { years } \\
\text { with the most points. }\end{array}$ & $\begin{array}{l}\text { Global } \\
\text { contributions. }\end{array}$ \\
\hline Self-employed & $\begin{array}{l}\text { Basic: All residents. } \\
\text { Earnings-related: All } \\
\text { self-employed earnings } \\
\text { over the base amount } \\
\text { (NOK } 56,861 \text { ) }\end{array}$ & $\begin{array}{l}\text { Basic and earnings- } \\
\text { related: } 10.7 \% \text { of } \\
\text { income up to } 12 \text { times } \\
\text { the base amount, plus } \\
7.8 \% \text { of income } \\
\text { exceeding } 12 \text { times } \\
\text { the base amount. } \\
\text { Farmers and } \\
\text { fishermen pay only } \\
7.8 \% \text {. }\end{array}$ & $\begin{array}{l}\text { The same as that of } \\
\text { employee's scheme. }\end{array}$ & $\begin{array}{l}\text { Global } \\
\text { contributions. } \\
\text { Despite of lower } \\
\text { contribution rates, } \\
\text { fishermen enjoy } \\
\text { very similar level of } \\
\text { benefits to those of } \\
\text { employees. It is } \\
\text { financed by a } \\
\text { special contribution } \\
\text { levied on the first } \\
\text { hand turnover } \\
\text { value of the catch. }\end{array}$ \\
\hline
\end{tabular}




\section{Poland}

All self-employed and their assisting persons who are not involved in agricultural work, are covered by the general scheme on a mandatory basis. There is a special separate scheme for farmers and their family members, and compulsory membership depends on the farmland size and other conditions.

\begin{tabular}{|c|c|c|c|c|c|}
\hline & & Coverage & Contributions & Benefits & Note \\
\hline \multicolumn{2}{|l|}{ Employee } & $\begin{array}{l}\text { Earnings-related: All } \\
\text { economically active } \\
\text { employed persons. } \\
\text { Defined contribution } \\
\text { (funded scheme): All } \\
\text { economically active } \\
\text { employed persons. }\end{array}$ & $\begin{array}{l}\text { Earnings-related: } \\
25.22 \% \text { ( } 8.96 \% \text { of } \\
\text { gross salary by } \\
\text { employee and } \\
16.26 \% \text { of gross } \\
\text { payroll by employer). } \\
\\
\text { Defined contribution: } \\
7.3 \% \text { of gross salary } \\
\text { by employee (no } \\
\text { contribution by } \\
\text { employer). }\end{array}$ & $\begin{array}{l}\text { Earnings-related: } \\
\text { Accumulated notional } \\
\text { capital is divided by the } \\
\text { "average life expectancy at } \\
\text { retirement age." } \\
\text { Defined contribution: An } \\
\text { annuity is purchased with } \\
\text { the funds from the } \\
\text { individual account. }\end{array}$ & \\
\hline \multirow[t]{2}{*}{$\begin{array}{l}\text { Self- } \\
\text { employed }\end{array}$} & Farmers & $\begin{array}{l}\text { Compulsory for farmers } \\
\text { who own more than one } \\
\text { hectare of land, and } \\
\text { their family members. }\end{array}$ & $\begin{array}{l}\text { Flat-rate (in 2002, } \\
\text { PLN } 663 \text { a year). } \\
\text { The contribution per } \\
\text { quarter is equal to } \\
30 \% \text { of the minimum } \\
\text { monthly pension. }\end{array}$ & $\begin{array}{l}\text { Contributory part: Benefits } \\
\text { that relates to the average } \\
\text { income of the insured. } \\
\text { Supplementary part: About } \\
25 \% \text { of the basic amount. }\end{array}$ & $\begin{array}{l}\text { Government } \\
\text { subsidy covers } \\
\text { approximately } \\
94 \% \text { of the } \\
\text { expenditure. }\end{array}$ \\
\hline & $\begin{array}{l}\text { The self- } \\
\text { employed }\end{array}$ & $\begin{array}{l}\text { Earnings-related: All } \\
\text { economically active self- } \\
\text { employed persons and } \\
\text { assisting family } \\
\text { members (those who } \\
\text { run their own non- } \\
\text { agricultural businesses, } \\
\text { creators and artists and } \\
\text { people performing so- } \\
\text { called "free } \\
\text { occupation"). } \\
\text { Defined contribution } \\
\text { (funded scheme): All } \\
\text { economically active self- } \\
\text { employed persons. }\end{array}$ & $\begin{array}{l}\text { Earnings-related: } \\
32.52 \% \text { of declared } \\
\text { income. } \\
\text { Defined contribution: } \\
7.3 \% \text { of declared } \\
\text { income. } \\
\text { Declared income } \\
\text { cannot be lower than } \\
60 \% \text { of the } \\
\text { calculated average } \\
\text { wage in the } \\
\text { economy. }\end{array}$ & $\begin{array}{l}\text { The same rules for } \\
\text { employee, but no right to } \\
\text { the early retirement } \\
\text { pension. }\end{array}$ & $\begin{array}{l}\text { Total insured's } \\
\text { number is } \\
14,320,000 \\
(2002) \text {. } \\
\text { Insured self- } \\
\text { employed is } \\
\text { estimated to } \\
1.2 \text { to } 1.4 \\
\text { million (around } \\
10 \%) \text {. Self- } \\
\text { employment } \\
\text { rate is } 28.1 \% \\
(2002) \text {. }\end{array}$ \\
\hline
\end{tabular}




\section{Portugal}

All self-employed persons are covered under the general scheme.

\begin{tabular}{|c|c|c|c|c|}
\hline & Coverage & Contributions & Benefits & Note \\
\hline Employee & $\begin{array}{l}\text { Earnings-related: } \\
\text { Compulsory for those } \\
\text { self-employed persons } \\
\text { whose gross yearly } \\
\text { income is higher than } 6 \\
\text { times the highest } \\
\text { minimum wage. }\end{array}$ & $\begin{array}{l}\text { Earnings-related: } \\
34.75 \% \text { ( } 11 \% \text { of } \\
\text { earnings by employee } \\
\text { and } 23.75 \% \text { of payroll } \\
\text { by employer). } \\
\text { Of the total } 34.75 \% \text {, } \\
16.01 \% \text { is allocated to } \\
\text { old-age benefits. }\end{array}$ & $\begin{array}{l}\text { The pension accrues at } \\
2 \% \text { of the earnings base } \\
\text { for each year of } \\
\text { contributions for } 20 \text { or } \\
\text { fewer years' } \\
\text { contributions. For } \\
\text { beneficiaries with } 21 \text { or } \\
\text { more years of } \\
\text { contributions, the accrual } \\
\text { rate ranges between } 2 \% \\
\text { and } 2.3 \% \text { depending on } \\
\text { earnings. }\end{array}$ & $\begin{array}{l}\text { Global } \\
\text { contributions. }\end{array}$ \\
\hline Self-employed & $\begin{array}{l}\text { Earnings-related: } \\
\text { Compulsory for those } \\
\text { self-employed persons } \\
\text { whose gross yearly } \\
\text { income is higher than } 6 \\
\text { times the highest } \\
\text { minimum wage. For } \\
\text { first time self-employed } \\
\text { persons affiliation is not } \\
\text { compulsory for the first } \\
12 \text { months } \\
\text { For others, } \\
\text { membership is } \\
\text { voluntary. } \\
\text { Lawyers and solicitors } \\
\text { are covered by a } \\
\text { specific insurance fund. }\end{array}$ & $\begin{array}{l}\text { Earnings-related: } \\
25.4 \% \text { of reference } \\
\text { income for mandatory } \\
\text { coverage and } 32 \% \text { of } \\
\text { reference income for } \\
\text { voluntary coverage. } \\
\text { The reference income } \\
\text { is chosen by the self- } \\
\text { employed person from } \\
\text { a range of one to } \\
\text { eleven times the } \\
\text { national minimum } \\
\text { wage. The national } \\
\text { minimum wage is } \\
€ 365.60 \text {. }\end{array}$ & $\begin{array}{l}\text { The same rule as that of } \\
\text { employee's. }\end{array}$ & $\begin{array}{l}\text { Global } \\
\text { contributions. }\end{array}$ \\
\hline
\end{tabular}




\section{DELSA/ELSA/WD/SEM(2009)12}

\section{Slovak Republic}

All self-employed persons are covered within the general scheme.

\begin{tabular}{|c|c|c|c|c|}
\hline & Coverage & Contributions & Benefits & Note \\
\hline Employee & $\begin{array}{l}\text { Earnings-related: } \\
\text { Employee. }\end{array}$ & $\begin{array}{l}\text { Earnings-related: } 4 \% \\
\text { of earnings for old-age } \\
\text { and survivor by } \\
\text { employee (another } \\
3 \% \text { of disability). } 19 \% \\
\text { of payroll by } \\
\text { employer. }\end{array}$ & $\begin{array}{l}\text { The pension reflects the } \\
\text { average personal wage } \\
\text { points which are based } \\
\text { on the ratio of individual } \\
\text { earnings to average } \\
\text { earnings. }\end{array}$ & \\
\hline Self-employed & $\begin{array}{l}\text { Earnings-related: Self- } \\
\text { employed persons. } \\
\text { Persons whose yearly } \\
\text { income is less than } \\
\text { SKK } 72,960(€ 1,809) \\
(12 \text { times of the } \\
\text { national minimum } \\
\text { wage) are exempt from } \\
\text { compulsory } \\
\text { membership. }\end{array}$ & $\begin{array}{l}\text { Earnings-related: } 26 \% \\
\text { of earnings ( } 20 \% \text { for } \\
\text { old-age and survivor, } \\
6 \% \text { for disability). } \\
\text { The contributions } \\
\text { base is } 50 \% \text { of } \\
\text { average monthly } \\
\text { taxable income over } \\
\text { the previous year. } \\
\text { There are upper and } \\
\text { lower ceilings. }\end{array}$ & $\begin{array}{l}\text { The same rule as that of } \\
\text { employee's. }\end{array}$ & \\
\hline
\end{tabular}




\section{Spain}

There are special individual schemes for farmers and other self-employed.

\begin{tabular}{|c|c|c|c|c|c|}
\hline & & Coverage & Contributions & Benefits & Note \\
\hline \multicolumn{2}{|l|}{ Employee } & $\begin{array}{l}\text { Employees in } \\
\text { industry and } \\
\text { services (classified } \\
\text { according to } 11 \\
\text { occupational } \\
\text { classes). }\end{array}$ & $\begin{array}{l}28.3 \% \text { ( } 4.7 \% \text { of } \\
\text { earnings by employee } \\
\text { and } 23.6 \% \text { by } \\
\text { employer). }\end{array}$ & $\begin{array}{l}50 \% \text { of the benefit base } \\
\text { for the first } 15 \text { years' } \\
\text { contribution, plus } 3 \% \\
\text { for each year between } \\
16 \text { and } 25 \text { years of } \\
\text { contributions and } 2 \% \\
\text { for each year beginning } \\
\text { with the } 26^{\text {th }} \text { year, up to } \\
\text { maximum } 100 \% \text {. }\end{array}$ & $\begin{array}{l}\text { Global } \\
\text { contributions. }\end{array}$ \\
\hline \multirow[t]{2}{*}{$\begin{array}{l}\text { Self- } \\
\text { employed }\end{array}$} & $\begin{array}{l}\text { Farmers } \\
\text { (R.E.A) }\end{array}$ & $\begin{array}{l}\text { Farmers and their } \\
\text { family members. }\end{array}$ & $\begin{array}{l}18.75 \% \text { of a tax base } \\
\text { (Tax base is legislated } \\
\text { annually and is only } \\
\text { weakly related to } \\
\text { average earnings). In } \\
2004 \text {, the contribution } \\
\text { basis is } € 596.70 \text { a } \\
\text { month. }\end{array}$ & $\begin{array}{l}\text { Essentially, the rules } \\
\text { correspond to those of } \\
\text { employee. } \\
\text { Partial retirement is not } \\
\text { covered. }\end{array}$ & \\
\hline & $\begin{array}{l}\text { The self- } \\
\text { employed } \\
\text { (R.E.T.A) }\end{array}$ & $\begin{array}{l}\text { Craftsmen, retailers, } \\
\text { etc. }\end{array}$ & $\begin{array}{l}26.5 \% \text { of covered } \\
\text { earnings (the self- } \\
\text { employed are } \\
\text { essentially free to } \\
\text { choose their covered } \\
\text { earnings between a } \\
\text { floor and a ceiling } \\
\text { legislated annually). } \\
\text { In } 2004 \text {, the } \\
\text { contribution basis } \\
\text { varies between a } \\
\text { minimum of } € 755.40 \\
\text { and a maximum of } \\
€ 2,731.50 \text {. }\end{array}$ & $\begin{array}{l}\text { Essentially, the rules } \\
\text { correspond to those of } \\
\text { employee. } \\
\text { Partial retirement is not } \\
\text { covered. }\end{array}$ & $\begin{array}{l}\text { Global } \\
\text { contributions. }\end{array}$ \\
\hline
\end{tabular}




\section{Sweden}

The Swedish social protection system is based on the principle of the national insurance. There is no distinction between employee and the self-employed.

\begin{tabular}{|c|c|c|c|c|}
\hline & Coverage & Contributions & Benefits & Note \\
\hline Employee & $\begin{array}{l}\text { Targeted: All } \\
\text { residents. } \\
\text { Earnings-related and } \\
\text { Defined contribution: } \\
\text { All employed earning } \\
\text { over SEK 17,800 a } \\
\text { year. } \\
\text { Quasi-mandatory } \\
\text { occupational: }\end{array}$ & $\begin{array}{l}18.91 \% \text { ( } 7 \% \text { of } \\
\text { assessable income by } \\
\text { employee and } 10.21 \% \\
\text { of payroll by employer). } \\
\text { Additional } 1.7 \% \text { for } \\
\text { survivor pension. } \\
\text { Quasi-mandatory } \\
\text { occupational: }\end{array}$ & $\begin{array}{l}\text { Targeted: SEK 83,707 } \\
\text { for single. } \\
\text { Earnings-related: The } \\
\text { accumulated notional } \\
\text { capital is converted to an } \\
\text { annuity. } \\
\text { Defined contribution: The } \\
\text { accumulated balance is } \\
\text { converted into an } \\
\text { annuity. } \\
\text { Quasi-mandatory } \\
\text { occupational: }\end{array}$ & \\
\hline Self-employed & $\begin{array}{l}\text { Targeted: All } \\
\text { residents. } \\
\text { Earnings-related and } \\
\text { Defined contribution: } \\
\text { All self-employed } \\
\text { earning over SEK } \\
17,800 \text { a year. } \\
\text { Quasi-mandatory } \\
\text { occupational: n/a }\end{array}$ & $\begin{array}{l}18.91 \% \text { ( } 7 \% \text { of } \\
\text { individual pension } \\
\text { contribution and } 10.21 \% \\
\text { of self-employment } \\
\text { contribution). Additional } \\
1.7 \% \text { for survivor } \\
\text { pension. } \\
\text { Quasi-mandatory } \\
\text { occupational: n/a }\end{array}$ & $\begin{array}{l}\text { The same as that of } \\
\text { employee's scheme. }\end{array}$ & \\
\hline
\end{tabular}




\section{Switzerland}

There is no special scheme for the self-employed. They are covered by the general scheme.

\begin{tabular}{|c|c|c|c|c|}
\hline & Coverage & Contributions & Benefits & Note \\
\hline Employee & $\begin{array}{l}\text { Earnings-related: All } \\
\text { residents. } \\
\text { Mandatory } \\
\text { occupational: } \\
\text { Employees whose } \\
\text { annual earnings } \\
\text { exceed CHF 25,320. }\end{array}$ & $\begin{array}{l}\text { Earnings-related: } 9.8 \% \\
\text { ( } 4.9 \% \text { by employee and } \\
4.9 \% \text { by employer). } \\
\text { Mandatory } \\
\text { occupational: } \\
\text { Employees contribute } \\
\text { from } 7 \% \text { to } 18 \% \text { of } \\
\text { income according to } \\
\text { their age. The } \\
\text { contribution by } \\
\text { employers is at least } \\
\text { equal to the employee's } \\
\text { contribution. }\end{array}$ & $\begin{array}{l}\text { Earnings-related: For } \\
\text { average lifetime earnings } \\
\text { (ALE) less than CHF } \\
37,080, \text { the pension is } \\
\text { CHF } 9,146 \text { plus } 26 \% \text { of } \\
\text { the ALE. For above this } \\
\text { level, a flat CHF } 12,854 \\
\text { plus } 16 \% \text { of the ALE. } \\
\text { Mandatory occupational: } \\
\text { An annual payment } \\
\text { equal to } 7.2 \% \text { of the } \\
\text { accumulated funds in the } \\
\text { personal account with } \\
\text { interest. }\end{array}$ & $\begin{array}{l}\text { Non-working } \\
\text { persons pay a } \\
\text { contribution } \\
\text { between } € 227 \text { and } \\
€ 5,411 \text { a year } \\
\text { according to their } \\
\text { social conditions. }\end{array}$ \\
\hline Self-employed & $\begin{array}{l}\text { Earnings-related: All } \\
\text { residents. } \\
\text { Mandatory } \\
\text { occupational: } \\
\text { Voluntary } \\
\text { membership. }\end{array}$ & $\begin{array}{l}\text { Earnings-related: } 9.2 \% \\
\text { of gross professional } \\
\text { income. Contributions } \\
\text { vary according to a } \\
\text { decreasing scale of } \\
\text { contributions. } \\
\text { Mandatory } \\
\text { occupational: Voluntary } \\
\text { contributions. }\end{array}$ & $\begin{array}{l}\text { Earnings-related: The } \\
\text { same as that of } \\
\text { employee. } \\
\text { Mandatory occupational: } \\
\text { Voluntary membership. }\end{array}$ & \\
\hline
\end{tabular}


DELSA/ELSA/WD/SEM(2009)12

\section{Turkey}

There is a special scheme (Bag-Kur) for the self-employed including farmers.

\begin{tabular}{|c|c|c|c|c|}
\hline & Coverage & Contributions & Benefits & Note \\
\hline Employee & $\begin{array}{l}\text { Earnings-related: } \\
\text { Employees aged } 18 \\
\text { or older working } \\
\text { under a service } \\
\text { contract in the public } \\
\text { or private sector. }\end{array}$ & $\begin{array}{l}\text { Earnings-related: } 20 \% \\
\text { of monthly earnings ( } 9 \% \\
\text { by employee and } 11 \% \\
\text { by employer). }\end{array}$ & $\begin{array}{l}\text { Earnings-related: The } \\
\text { first } 10 \text { years earn a } \\
\text { pension of } 35 \% \text { of pay, } \\
\text { with } 2 \% \text { per year extra } \\
\text { for the next } 15 \text { years and } \\
1.5 \% \text { per year. }\end{array}$ & \\
\hline Self-employed & $\begin{array}{l}\text { Earnings-related: } \\
\text { Self-employed urban } \\
\text { workers and farmers. }\end{array}$ & $\begin{array}{l}\text { Earnings-related: } 20 \% \\
\text { of professional income. }\end{array}$ & $\begin{array}{l}\text { Earnings-related: The } \\
\text { same as that of } \\
\text { employee. }\end{array}$ & \\
\hline
\end{tabular}

\section{Note.}

1) In 2002, the number of the insured self-employed including farmers are $15,548,000$ while total insured's number is $61,832,000$ $(25 \%)$. The self-employment rate is $49.4 \%$.

2) The total size of the informal or unregistered sector is estimated at around $52 \%$ of total employment including agriculture, and $37 \%$ in private sector employment excluding agriculture.

3) The collection rate of the pension scheme for the self-employed is very low. 


\section{United Kingdom}

The general social protection system basically covers the self-employed.

\begin{tabular}{|c|c|c|c|c|}
\hline & Coverage & Contributions & Benefits & Note \\
\hline Employee & $\begin{array}{l}\text { Employed persons } \\
\text { aged } 16 \text { to } 65 \text { (men) } \\
\text { or aged } 16 \text { to } 60 \\
\text { (women) with weekly } \\
\text { earnings of at least } \\
£ 77 .\end{array}$ & $\begin{array}{l}\text { Employee: } 11 \% \text { of } \\
\text { weekly earnings } \\
\text { between } £ 91 \text { and } £ 610 \text {. } \\
\text { Employer: } 12.8 \% \text { of } \\
\text { employee's earnings } \\
\text { over } £ 91 \text { a week. }\end{array}$ & $\begin{array}{l}\text { Basic: } £ 75.50 \text { a week in } \\
2002-2003 \text { for a single } \\
\text { person. } \\
\text { Earnings-related: The } \\
\text { accrual rate varies } \\
\text { depending on the level } \\
\text { and year of earnings and } \\
\text { the date of retirement. }\end{array}$ & $\begin{array}{l}\text { Global } \\
\text { contributions. } \\
\text { The pension credit } \\
\text { (means-tested) is } \\
\text { available to all } \\
\text { residents aged } 60 \\
\text { or older. }\end{array}$ \\
\hline Self-employed & $\begin{array}{l}\text { Self-employed } \\
\text { persons aged } 16 \text { to } \\
65 \text { (men) or aged } 16 \\
\text { to } 60 \text { (women) with } \\
\text { annual income of at } \\
\text { least } £ 4,095 \text {. } \\
\text { The state second } \\
\text { pension is not } \\
\text { applied. }\end{array}$ & $\begin{array}{l}\text { Earnings-related: } A \text { flat- } \\
\text { rate contribution of } \\
£ 2.05 \text { a week if } \\
\text { earnings are more than } \\
£ 4,215 \text {. Self-employed } \\
\text { persons with annual } \\
\text { profits between } £ 4,745 \\
\text { and } £ 31,720 \text { pay an } 8 \% \\
\text { plus } 1 \% \text { of any profits } \\
\text { above } £ 31,720 \text {. }\end{array}$ & $\begin{array}{l}\text { Basic: The same as that } \\
\text { of employee. } \\
\text { Earnings-related: } \\
\text { Voluntary contributions. }\end{array}$ & $\begin{array}{l}\text { Global } \\
\text { contributions. } \\
\text { The pension credit } \\
\text { (means-tested) is } \\
\text { available to all } \\
\text { residents aged } 60 \\
\text { or older. }\end{array}$ \\
\hline
\end{tabular}


DELSA/ELSA/WD/SEM(2009)12

\section{United States}

The general social protection system basically covers the self-employed.

\begin{tabular}{|c|c|c|c|c|}
\hline & Coverage & Contributions & Benefits & Note \\
\hline Employee & $\begin{array}{l}\text { Earnings-related: } \\
\text { Gainfully occupied } \\
\text { employed persons. } \\
\text { Casual agricultural } \\
\text { and domestic } \\
\text { employees are } \\
\text { excluded. }\end{array}$ & $\begin{array}{l}\text { Earnings-related: } 12.4 \% \\
(6.2 \% \text { by employee and } \\
6.2 \% \text { by employer). }\end{array}$ & $\begin{array}{l}\text { Earnings-related: The } \\
\text { first USD } 592 \text { a month of } \\
\text { relevant earnings } \\
\text { attracts a } 90 \% \\
\text { replacement rate. The } \\
\text { band of earnings } \\
\text { between USD } 592 \text { and } \\
\text { USD } 3,567 \text { a month is } \\
\text { replaced at } 3 \% \text {. }\end{array}$ & \\
\hline Self-employed & $\begin{array}{l}\text { Earnings-related: } \\
\text { Gainfully occupied } \\
\text { self-employed } \\
\text { persons. Some } \\
\text { categories of self- } \\
\text { employed (when } \\
\text { annual net income is } \\
\text { below USD 400) are } \\
\text { excluded. }\end{array}$ & $\begin{array}{l}\text { Earnings-related: } 12.4 \% \\
\text { of self-employment } \\
\text { income (gross earnings } \\
\text { minus allowable } \\
\text { business deductions). }\end{array}$ & $\begin{array}{l}\text { The same as that of } \\
\text { employee. }\end{array}$ & \\
\hline
\end{tabular}




\section{OECD SOCIAL, EMPLOYMENT AND MIGRATION WORKING PAPERS}

Most recent releases are:

No. 83 WORK, JOBS AND WELL-BEING ACROSS THE MILLENNIUM Andrew Clark (2009)

No. 82 CHILD WELL-BEING AND SOLE PARENT FAMILY STRUCTURE IN THE OECD: AN ANALYSIS Simon Chapple (2009)

No. 81 A GOOD TIME FOR MAKING WORK PAY? TAKING STOCK OF IN-WORK BENEFITS AND RELATED MEASURES ACROSS THE OECD

Herwig Immervoll and Mark Pearson (2009)

No. 80 MAIN FEATURES OF THE PUBLIC EMPLOYMENT SERVICE IN POLAND Daniela Kalužná (2009)

No. 79 MANAGING HIGHLY-SKILLED LABOUR MIGRATION: A COMPARATIVE ANALYSIS OF MIGRATION POLICIES AND CHALLENGES IN OECD COUNTRIES

Jonathan Chaloff and Georges Lemaitre (2009)

No. 78 ACTIVATION POLICIES IN NORWAY

Nicola Duell, Shruti Singh and Peter Tergeist (2009)

No. 77 PENSION, PURCHASING-POWER RISK, INFLATION AND INDEXATION Edward Whitehouse (2009)

No. 76 AN EVALUATION OF THE TAX-TRANSFER TREATMENT OF MARRIED COUPLES IN EUROPEAN COUNTRIES

Herwig Immervoll, Henrik Jacobsen Kleven, Claus Thustrup Kreiner and Nicolaj Verdelin (2009)

No. 75 ACTIVATION POLICIES IN IRELAND

David Grubb, Shruti Singh and Peter Tergeist (2009)

No. 74 MAIN FEATURES OF THE PUBLIC EMPLOYMENT SERVICE IN THE CZECH REPUBLIC Daniela Kaluzna (2008)

No. 73 LONG TIME-SERIES FOR PUBLIC EXPENDITURE ON LABOUR MARKET PROGRAMMES David Grubb and Agnès Puymoyen (2008)

No. 72 MAIN FEATURES OF THE PUBLIC EMPLOYMENT SERVICE IN THE SLOVAK REPUBLIC Daniela Kaluzna (2008)

No. 71 SOCIO-ECONOMIC DIFFERENCES IN MORTALITY Edward Whitehouse and Asghar Zaidi (2008)

No. 70 INVESTMENT RISK AND PENSIONS: MEASURING UNCERTAINTY IN RETURNS Anna d'Addio, Jose Seisdedod and Edward Whitehouse (forthcoming)

No. 69 FILLING THE PENSION GAP: COVERAGE AND VALUE OF VOLUNTARY RETIREMENT SAVINGS Antolin, P. and Edward Whitehouse (2009) (forthcoming)

No. 68 THE IMPACT OF FOREIGN DIRECT INVESTMENT ON WAGES AND WORKING CONDITIONS Elena Arnal and Alex Hijzen (2008)

No. 67 THE DYNAMICS OF SOCIAL ASSISTANCE RECEIPT: MEASUREMENT AND MODELLING ISSUES, WITH AN APPLICATION TO BRITAIN

Lorenzo Cappellari and Stephen P. Jenkins

Other series of working papers available from the OECD include: OECD HEALTH WORKING PAPERS 
DELSA/ELSA/WD/SEM(2009)12

\section{RECENT RELATED OECD PUBLICATIONS:}

PENSIONS AT A GLANCE - SPECIAL EDITION: ASIA/PACIFIC (2009)

GROWING UNEQUAL? Income Distribution and Poverty in OECD Countries (2008)

SICKNESS, DISABILITY AND WORK: BREAKING THE BARRIERS (VOL. 3) - DENMARK, FINLAND, IRELAND AND THE NETHERLANDS (2008)

JOBS FOR YOUTH: JAPAN (2008)

JOBS FOR YOUTH: CANADA (2008)

JOBS FOR YOUTH: NETHERLANDS (2008)

JOBS FOR YOUTH: NEW ZEALAND (2008)

JOBS FOR YOUTH: NORWAY (2008)

JOBS FOR YOUTH: UNITED KINGDOM (2008)

A PROFILE OF IMMIGRANT POPULATIONS IN THE $21^{\text {ST }}$ CENTURY (2008)

OECD EMPLOYMENT OUTLOOK (2008)

OECD LABOUR FORCE STATISTICS: 1987-2007 (2008)

INTERNATIONAL MIGRATION OUTLOOK - 2008 Edition

IMMIGRATION HEALTH WORKERS IN OECD COUNTRIES IN THE BROADER CONTEXT OF HIGHLY SKILLED MIGRATION (2008)

OECD REVIEWS OF LABOUR MARKET AND SOCIAL POLICIES IN SERBIA (2008)

JOBS FOR IMMIGRANTS (VOL. 2): Labour Market Integration in Belgium, France, The Netherlands and Portugal (2008)

MODERNISING SOCIAL POLICY FOR THE NEW LIFE COURSE (2007)

BABIES AND BOSSES - Reconciling Work and Family Life: A Synthesis of Findings for OECD Countries (2007)

BENEFITS AND WAGES - OECD Indicators (2007)

FACING THE FUTURE: KOREA'S FAMILY, PENSION AND HEALTH POLICY CHALLENGES (2007)

PENSIONS AT A GLANCE: Public policies across OECD countries (2007)

JOBS FOR YOUTH: KOREA (2007)

JOBS FOR YOUTH: BELGIUM (2007)

JOBS FOR YOUTH: SPAIN (2007)

JOBS FOR YOUTH: SLOVAK REPUBLIC (2007)

SICKNESS, DISABILITY AND WORK: BREAKING THE BARRIERS (VOL. 2) - AUSTRALIA, LUXEMBOURG, SPAIN AND THE UNITED KINGDOM (2007)

WOMEN AND MEN IN OECD COUNTRIES (2006)

For a full list, consult the OECD On-Line Bookstore at www.oecd.org 